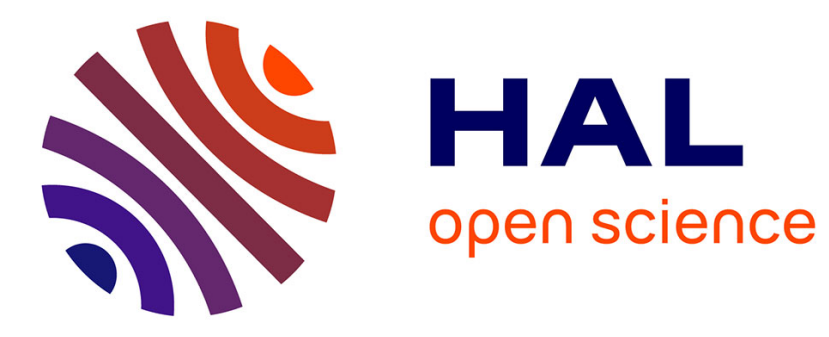

\title{
Does the Oxa-Michael Reaction of 2-Trifluoromethacrylic Acid Lead to Original Fluorinated Polyester?
}

Minh-Loan Tran-Do, Nadim Eid, Cédric Totée, Olinda Gimello, Bruno Ameduri

\section{To cite this version:}

Minh-Loan Tran-Do, Nadim Eid, Cédric Totée, Olinda Gimello, Bruno Ameduri. Does the OxaMichael Reaction of 2-Trifluoromethacrylic Acid Lead to Original Fluorinated Polyester? Polymer Chemistry, 2021, 12 (31), pp.4508-4523. 10.1039/d1py00685a . hal-03325690

\section{HAL Id: hal-03325690 https://hal.science/hal-03325690}

Submitted on 25 Aug 2021

HAL is a multi-disciplinary open access archive for the deposit and dissemination of scientific research documents, whether they are published or not. The documents may come from teaching and research institutions in France or abroad, or from public or private research centers.
L'archive ouverte pluridisciplinaire $\mathbf{H A L}$, est destinée au dépôt et à la diffusion de documents scientifiques de niveau recherche, publiés ou non, émanant des établissements d'enseignement et de recherche français ou étrangers, des laboratoires publics ou privés. 


\title{
May the Oxa-Michael Reaction of 2-Trifluoromethacrylic Acid Lead to Original Fluorinated Polyester?
}

\author{
Minh-Loan Tran-Do, Nadim Eid, Cédric Totée, Olinda Gimello, Bruno Améduri* \\ Institut Charles Gerhardt, Univ. Montpellier, CNRS, ENSCM, Montpellier, France. E-mail: \\ bruno.ameduri@enscm.fr
}

\begin{abstract}
2-Trifluoromethacrylic acid (MAF) is a peculiar fluorinated functional monomer. Though it is known to polymerise via $\mathrm{C}=\mathrm{C}$ bond cleavage under anionic initiation, its oxa-Michael addition polymerisation afforded polyesters bearing trifluoromethyl side groups. This oxa-Michael addition was attempted in the presence of radical (peroxides), basic (amines, phosphines) and acidic ( $\mathrm{AlCl}_{3}$, triflic acid, $p$ toluenesulfonic acid) reactants and catalysts which led to oligomers in various yields (up to $57 \%$ ) and molar masses (up to $2200 \mathrm{~g} \cdot \mathrm{mol}^{-1}$ ). The obtained polyestes were characterised by GC/MS, IR, ${ }^{19} \mathrm{~F},{ }^{1} \mathrm{H}$ and ${ }^{13} \mathrm{C}$ NMR spectroscopies, MALDI-TOF and their thermal properties were determined by thermogravimetric analysis and differentiel scanning calorimetry. Triphenylphosphine and piperidine led to the highest degree of polymerization $\mathrm{DP}_{\mathrm{n}}$ (up to $16^{\text {th }}$ adduct) with a degradation temperature of about $200{ }^{\circ} \mathrm{C}$. The glass transition temperatures $\left(T_{\mathrm{g}}\right)$ were -59 and $-46{ }^{\circ} \mathrm{C}$ for MAF bisadduct (diMAF) and oligoMAF, respectively. Such oligomers were hydrophobic, evidenced by water contact angle measurement of $107^{\circ}$ showing that the contribution of trifluoromethyl group was higher than that of the ester function.
\end{abstract}

\section{Introduction}

Polyesters are considered as a solution for the sustainability problems resulting from the plastics waste in the environnement because their production requires lower energy than other materials such as polyamides. Additionnally, they have a good biodegrability thanks to the labile ester bonds as target sites for enzymatic or catalytic chemical attack, releasing carboxylic acid and hydroxyl residues. ${ }^{1}$ Various polyesters and co-polyesters have been industrially produced, essentially by esterification of diols and diacids, or ring-opening of lactone-type monomers, ${ }^{2-4}$ but rarely by oxaMichael addition from unsaturated carboxylic acids.

Oxa-Michael addition is an addition of a nucleophilic oxygenated group, usually an alcohol as Michael donnor, onto a compound bearing a conjugated system, called « Michael acceptor ». ${ }^{5}$ Alcoolates, the most known Michael donor, are good nucleophiles whereas carboxylates are moderate ones. This is explained by negative charge centered on the oxygen atom of alcoolate but delocalised by resonance 
on both oxygen atoms of carboxylate, making the latter less nucleophilic. Using carboxylate as Michael donor requires a good Michael acceptor, under catalytic or harsh conditions. Oxa-Michael addition using conjugated carboxilic acid, whether as Michael donor ${ }^{6,7}$ or acceptor, ${ }^{8}$ was reported in few articles in organic synthesis field.

Polymerisation of monomer bearing vinyl functions can be achieved either under radical or ionic initiations. More scarcely, unsatured carboxylic acids and derivatives might also be polymerised via oxa-Michael process. One typical example is acrylic acid (AA) that easily polymerises under radical conditions by $\pi$ orbital cleavage in $\mathrm{C}=\mathrm{C}$ bond, but has also been involved in oxa-Michael addition, affording polyesters in low molar masses (Scheme 1). ${ }^{9-13}$ In addition, dimer of AA was firstly observed under its storage conditions. ${ }^{13,14}$

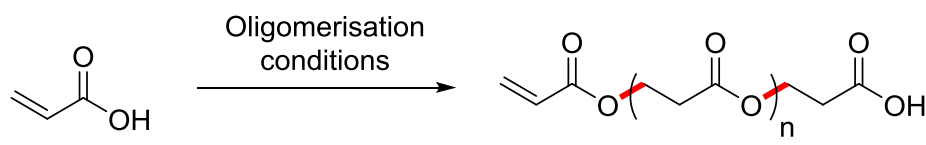

Scheme 1 : Oxa-Michael addition homopolymerisation of acrylic acid

According to Matsuoka's group, ${ }^{15}$ Lewis bases such as phosphines and $\mathrm{N}$-heterocyclic carbene (NHC) underwent Michael addition to AA, followed by proton transfer as step-growth polymerisation, which produces a variety of polymers (random and telechelic ones). On the other hand, strong Brønsted acid catalysts (especially sulfonic acids) activate the carbonyl group of AA, affording high molar mass polyesters. ${ }^{9}$ However, the use of $\mathrm{Ti}\left(\mathrm{O}^{i} \mathrm{Pr}\right)_{4}, 4-\mathrm{MeOC}_{6} \mathrm{H}_{4} \mathrm{OH}$, hydroquinone and $\mathrm{CuCl}$ at 140 ${ }^{\circ} \mathrm{C}$ led to oligomer with $\mathrm{DP}_{\mathrm{n}}$ close to $2 .{ }^{10,11}$

As a matter of fact, 2-trifluoromethacrylic acid (MAF) is an attractive synthon ${ }^{16}$ and precursor of functionnal monomers. ${ }^{17,18}$ One of our research topics is exploring the reactivity of MAF and applying it in different polymerisation procedures, such as co- and terpolymerisations. According to the literature, MAF cannot be polymerised from radical initiation ${ }^{19,20}$ but both its electron-withdrawing trifluoromethyl and carboxylic acid enable it to be polymerised under anionic conditions. ${ }^{21-23}$ Hence, it can be copolymerised with electron-donating monomers (e.g., $\alpha$-alkenes, ${ }^{24}$ norbornene, ${ }^{25,26}$ vinyl ethers ${ }^{27}$ ) and also with vinylidene fluoride (VDF). ${ }^{18,28}$

However, contrarily to such reactions, to the best of our knowledge, the oxa-Michael addition of MAF was mentioned in only two reports. First, in 2003, a Japanese patent claimed the polymerisation of MAF via an oxa-Michael poly(addition) leading to adducts of low molar masses in the presence of triethylamine but this report lacks of many clues and evidences to really identify the expected structures of such resulting oligomers. ${ }^{29}$ Second, in 2009, an analytical article reported the same polymerisation which occurred under UV radiation $(365 \mathrm{~nm})$ at $4{ }^{\circ} \mathrm{C}$ for $15 \mathrm{~h}$, then at $100{ }^{\circ} \mathrm{C}$ for $1 \mathrm{~h}$. 
During the ephedrine titration in the presence of $\mathrm{MAF}$ in $\mathrm{CDCl}_{3}, \mathrm{MAF}$ polymers were also observed, as undesired products. The mixture was then characterized by ${ }^{1} \mathrm{H}$ NMR spectroscopy. Despite the given assignments, MAF polymers were not isolated and no other analyses were supplied. ${ }^{30}$ Thus, it has been of interest to deeper investigate a similar reaction, taking into account the experimental conditions of the reaction involving acrylic acid, and considering that MAF contains a specific trifluoromethyl group that may greatly influence the electronic effects and thus the reactivity of this monomer. Hence, the objective of this article is to synthesise and characterise fluorinated polyesters based on MAF by oxa-Michael addition.

\section{Materials and Methods}

Chemicals . 2-trifluoromethacrylic acid (MAF) and tert-butylperoxypivalate (tBuOOC(O)tBu, TBPPi) (75\%) were kindly offered by Tosoh Fine Chemicals Company (Shunan, Japan) and Akzo Nobel (Chalons sur Marne, France), respectively. $\mathrm{KOH}$, 2,2,6,6-tetramethylpiperidine, piperidine, 1,8diazabicyclo[5.4.0]undec-7-ene (DBU), $N, N$-diisopropylethylamine (DIPEA), $\mathrm{P}\left(n \mathrm{Bu}_{3}\right)_{3}, \mathrm{PPh}_{3}$, concentrated $\mathrm{HCl}, \mathrm{FeSO}_{4} \cdot 7 \mathrm{H}_{2} \mathrm{O}, \mathrm{B}\left(\mathrm{C}_{6} \mathrm{~F}_{5}\right)_{3}, \mathrm{AlCl}_{3}, \mathrm{MgSO}_{4}, p$-toluenesulfonic acid monohydrate (PTSA. $\left.\mathrm{H}_{2} \mathrm{O}\right)$, triflic acid, tricyclohexylphosphine $\mathrm{P}\left(\mathrm{C}_{6} \mathrm{H}_{11}\right)_{3}$, racemic $\left(2,2^{\prime}\right.$-bis(diphenylphosphino)-1,1'binaphthyl) (BINAP) and Amberlyst 15 were purchased from Aldrich Sigma, Fischer Scientific, Acros Organics and FluoroChem and used without further purification.

Gas chromatography coupled with mass spectrometry (GC/MS). GC model was GC-2010 Plus Shimadzu with injection port SPL1 (temperature : $250^{\circ} \mathrm{C}$; flow $26.6 \mathrm{~mL} / \mathrm{min}$; purge flow $3 \mathrm{~mL} / \mathrm{min}$, inlet pressure $100 \mathrm{kPa}$ ) and column Zebron ZB-5MS (total flow $26.6 \mathrm{~mL} / \mathrm{min}$; colum flow 0.76 $\mathrm{mL} / \mathrm{min}$; linear velocity $38.2 \mathrm{~cm} / \mathrm{sec}$; purge flow $3 \mathrm{~mL} / \mathrm{min}$ ). GC Column dimensions were $20 \mathrm{~m}$ of length $\times 0.18 \mathrm{~mm}$ of inner diameter $\times 0.18 \mu \mathrm{m}$ of film thickness. The carrier gas was He and the column oven temperature was programmed from $30^{\circ} \mathrm{C}$ isothermal for $5 \mathrm{~min}$ then $22{ }^{\circ} \mathrm{C} / \mathrm{min}$ to 280 ${ }^{\circ} \mathrm{C}$ and isothermal for $5 \mathrm{~min}$. MS model was GCMS-QP2010SE which is a quadrupole mass spectrometer equipped with electron ionisation at $200{ }^{\circ} \mathrm{C}$. The measurements were performed in full-scan mode (m/z 2.0-800).

Nuclear magnetic resonance (NMR) spectroscopy. The ${ }^{13} \mathrm{C},{ }^{1} \mathrm{H}$ and ${ }^{19} \mathrm{~F}$ NMR spectra (Figures 1-2) were recorded on Bruker Avance 400 instruments, using $\mathrm{CDCl}_{3}$ as deuteurated solvent, signal of which was calibrated at $7.26 \mathrm{ppm}$. Hexafluorobenzene $\mathrm{C}_{6} \mathrm{~F}_{6}$ was used as internal standard for ${ }^{19} \mathrm{~F}$ NMR analysises, its signal was calibrated at $-164.9 \mathrm{ppm}$. Coupling constants and chemical shifts are given in Hertz $(\mathrm{Hz})$ and parts per million $(\mathrm{ppm})$, respectively. The experimental conditions for recording ${ }^{1} \mathrm{H}$ [or ${ }^{19} \mathrm{~F}$ ] NMR spectra were as follows: angle $90^{\circ}$ [or $30^{\circ}$ ], acquisition time $4.5 \mathrm{~s}$ [or $0.7 \mathrm{~s}$ ], pulse delay $2 \mathrm{~s}$ [or $5 \mathrm{~s}$ ], number of scans 36 [or 64], and a pulse width of $5 \mu \mathrm{s}$ for ${ }^{19} \mathrm{~F}$ NMR. ${ }^{1} \mathrm{H}$ 
decoupling is applied on all ${ }^{13} \mathrm{C}$ NMR analyses and almost on Attached Proton Test mode $\left({ }^{13} \mathrm{C}\left\{{ }^{1} \mathrm{H}\right\}\right.$ APT). In the details of NMR characterisation, $s, d, t, q$, and $m$ stand for singlet, doublet, triplet, quintet, and multiplet, respectively.

For 2D NMR spectroscopy, HMQC spectrum (Figure 3) was obtained with 2048 points in the $\mathrm{F} 1\left({ }^{13} \mathrm{C}\right.$ ) dimension and 8192 points in $\mathrm{F} 2\left({ }^{1} \mathrm{H}\right)$ one, a spectral width of $25.2 \mathrm{kHz}$ in $\mathrm{F} 1$ and $8.0 \mathrm{kHz}$ in F2. Acquisition times were $0.04 \mathrm{~s}$ in F1 and $0.5 \mathrm{~s}$ in F2. Two scans were applied to lead to a suitable signal/noise ratio and to respect phase of the pulse program sequence. A relaxation delay of $1.5 \mathrm{~s}$ was chosen.

HeteroCOSY ${ }^{1} \mathrm{H}_{-}^{19} \mathrm{~F}$ spectrum (Figure S16) was obtained with 1400 points in the $\mathrm{F} 1\left({ }^{1} \mathrm{H}\right)$ dimension and 15058 points in $\mathrm{F} 2\left({ }^{19} \mathrm{~F}\right)$ one, a spectral width of $4.0 \mathrm{kHz}$ in $\mathrm{F} 1$ and $7.5 \mathrm{kHz}$ in F2. Acquisition times were $0.17 \mathrm{~s}$ in F1 and $1.0 \mathrm{~s}$ in F2. Eight scans and relaxation delay of $1 \mathrm{~s}$ were applied.

gHSQC spectrum (Figure S17) was obtained with 1024 points in the $\mathrm{F} 1\left({ }^{13} \mathrm{C}\right)$ dimension and 7528 points in $\mathrm{F} 2\left({ }^{19} \mathrm{~F}\right)$ one, with a spectral width of $20.1 \mathrm{kHz}$ in $\mathrm{F} 1$ and $3.8 \mathrm{kHz}$ in $\mathrm{F} 2$. Acquisition times were $0.03 \mathrm{~s}$ in $\mathrm{F} 1$ and $1.0 \mathrm{~s}$ in F2. Eight scans and relaxation delay of $1 \mathrm{~s}$ were applied. ${ }^{1} \mathrm{H}$ decoupling was applied during the whole sequence.

Matrix-Assisted Laser Desorption Ionisation (MALDI-TOF) spectrometry. MALDI-TOF mass spectra were recorded using a Bruker Rapiflex time-of-flight mass spectrometer using a nitrogen laser for MALDI ( $\lambda 337 \mathrm{~nm}$ ). The measurements in positive ion mode were performed with a voltage and reflector lens potential of 25 and $20 \mathrm{kV}$, respectively. Mixtures of peptides were used for external calibration. The matrix and cationising agent were trans-2-[3-(4-tertbutylphenyl)-2-methylprop-2enylidene]malononitrile (DCTB, $10 \mathrm{mg} \cdot \mathrm{mL}^{-1}$ in $\mathrm{CHCl}_{3}$ ) and sodium iodide ( $\mathrm{Nal}, 6 \mathrm{mg} \cdot \mathrm{mL}^{-1}$ in methanol), respectively. The polymer concentration was $20 \mathrm{mg} \cdot \mathrm{mL}^{-1}$ in dichloromethane. The polymer and matrix were mixed in a $5: 10$ volume ratio. Nal was first deposited on the target. After evaporation of the solvent, the mixture, composed of the polymer and matrix, was placed on the MALDI target. The dry droplet sample preparation method was used.

Thermogravimetric analysis (TGA). The thermogravimetric analysis of the polymers (ca. $10 \mathrm{mg}$ ) was carried out under $\mathrm{N}_{2}$ with a TA Instruments TGA 51 apparatus. The polymer samples were heated from 20 to $400{ }^{\circ} \mathrm{C}$ at a heating rate of $20^{\circ} \mathrm{C} \mathrm{min}^{-1}$.

Fourier transform infrared (FTIR) spectroscopy. FTIR analyses of the copolymers were performed using a PerkinElmer Spectrum 1000 in ATR mode, with an accuracy of $\pm 2 \mathrm{~cm}^{-1}$.

Differential scanning calorimetry (DSC). DSC analysis, under $\mathrm{N}_{2}$ atmosphere, of the purified oligoMAF (ca. $10 \mathrm{mg}$ ) was carried out using a TA instruments Q100 instrument equipped with DSC 
200 F3 software. The instrument was calibrated with noble metals and checked before analysis with an indium sample $\left(T_{m}=156.6^{\circ} \mathrm{C}\right)$. After its insertion into the DSC apparatus, the sample was cooled down from $20^{\circ} \mathrm{C}$ to $-120^{\circ} \mathrm{C}$ and stabilized at latter temperature for $12 \mathrm{~min}$. Then, the first scan was performed at a heating rate of $10{ }^{\circ} \mathrm{C} \mathrm{min}^{-1}$ up to $30{ }^{\circ} \mathrm{C}$. The cycle cooling to $-120^{\circ} \mathrm{C}$, stabilizing and warming up to $30^{\circ} \mathrm{C}$ was repeated two more times. $T_{\mathrm{g}}$ was evaluated from three heatings, taken at the half-height of the heat capacity jump of the glass transition. The sample was amorphous and the glass transition temperature was determined by the inflection point in the heat capacity jump of the third scan.

Water contact angle (WCA). WCA measurements were carried out on Contact Angle System OCAData Physics. The water sessile drop method was used for the statics contact angle (CA) measurements at ambient temperature. The probe liquid was water $\left(\theta_{\mathrm{H} 2 \mathrm{O}}\right)$ and the average $\mathrm{CA}$ value was determined on five different drops of $c a .4 .0 \mu \mathrm{L}$ deposited on the same sample. OligoMAF coating was prepared by casting onto a glass slide from oligoMAF dissolved in dichloromethane.

Polymerisation procedure. In a reaction tube (Figure S1a) equipped with a magnetic stirrer, were introduced MAF and additive. The tube was purged under $\mathrm{N}_{2}$ before being sealed and immersed into an oil bath heated at the requested temperature. The polymerisation was stopped after 24 hours by cooling the tube to room temperature. Immersion of the tube enabled to prevent the sublimation of MAF. Compared to round bottom flasks, the tubes allow to easily proceed simultaenous several (4 in the case of our experiments) reactions in 1.4 gram scale (Figure S1b). For reactions with amines, a filtration over Amberlyst 15 was nessecary to remove the produced ammonium (Scheme S1 \& Figure S2). A subsequent sublimation at $60-70{ }^{\circ} \mathrm{C}$ under reduced pressure was achieved to remove the unreacted MAF and afforded oligoMAF as a yellowish and translucient wax. A more detailed description is supplied in the electronic Supplementary Information.

\section{Results and discussion}

To the best of our knowledge, the oligomerisation of MAF by oxa-Michael addition leading to low molar mass-oligomers was claimed in Japanese patent ${ }^{29}$ and an analytical publication. ${ }^{30}$ However, only the descriptions from ${ }^{1} \mathrm{H}$ and ${ }^{13} \mathrm{C}$ NMR spectra of the dimer and trimer were reported. Thus, it was worth to confirm this formation by means of complementary techniques as ${ }^{19} \mathrm{~F}, 2 \mathrm{D}$ NMR and IR spectrocopies, GC/MS and MALDI-TOF analyses, as well as to attempt increasing the average degree of polymerisation $\left(D_{n}\right)$.

Based on the oligomerisation acrylic acid, polymerisation of MAF was then studied. Actually, $\mathrm{CF}_{3}$ substituent makes MAF much more acidic than $A A\left(p K a(M A F)=-2.1 ;^{31} \mathrm{pKa}(\mathrm{AA})=4.25\right)^{32}$ and might lead to significant change in term of reactivity under polymerisation conditions (Scheme 2). This 
section is composed of two parts : i) first, the characterisations of oligoMAF are supplied and then ii) the influences of the experimental (radical, basic or acidic) conditions on the MAF conversion and $\mathrm{DP}_{\mathrm{n}}$ are studied.

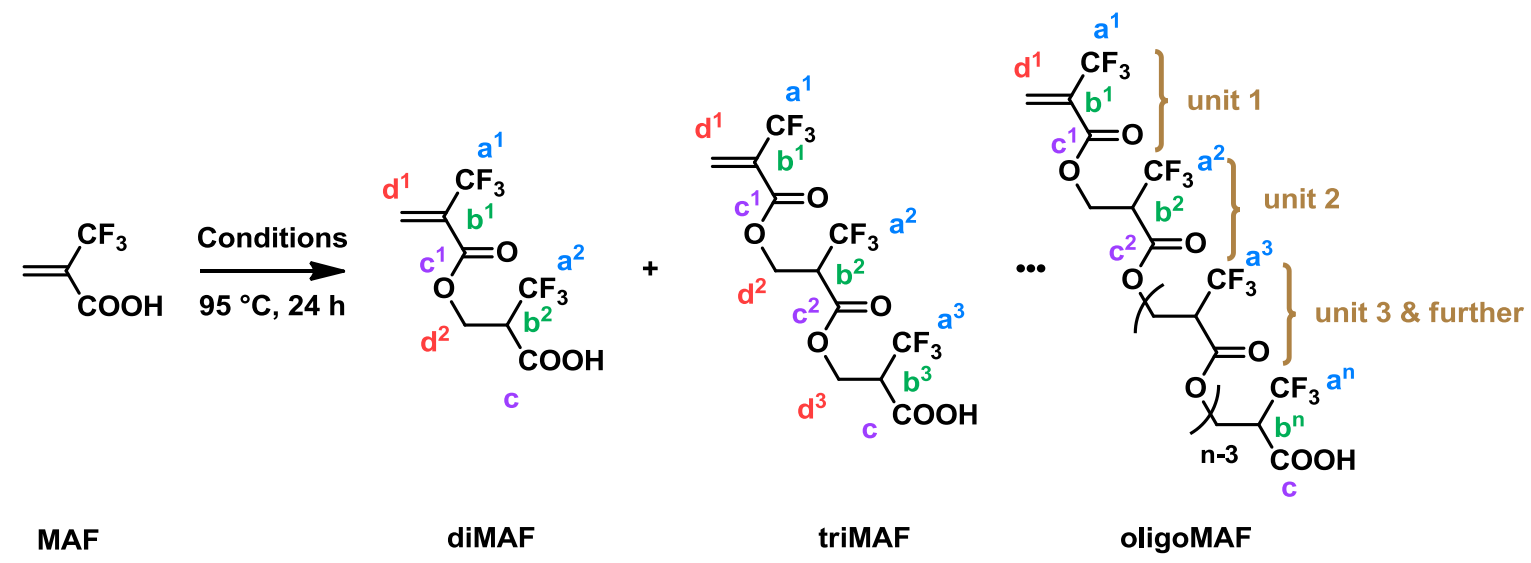

Scheme 2: Oligomerisation of MAF by oxa-Michael addition yielding fluorinated oligo(ester)s

\subsection{Characterisation of oligo(MAF)s}

\section{Nuclear magnetic resonance (NMR) spectroscopy}

After purification and drying, the oligo(MAF)s were analysed by NMR, GC/MS, MALDI and IR. The characterisation of oligoMAF was achieved by comparing those of MAF, diMAF and triMAF.

MAF. The NMR spectrum of MAF (Figure S4) shows two quartets centered at $6.88 \mathrm{ppm}\left({ }^{4} J_{\mathrm{HFtrans}}=1.8\right.$ $\mathrm{Hz})$ and $6.60 \mathrm{ppm}\left({ }^{4} J_{\mathrm{HFC} \text { is }}=1.3 \mathrm{~Hz}\right)$ assigned to ethylenic $\mathrm{CH}_{2}=$ of MAF and a doublet $\left({ }^{4} J_{\mathrm{FH}}=1.7 \mathrm{~Hz}\right)$ of doublets $\left({ }^{4} J_{\mathrm{FH}}=1.3 \mathrm{~Hz}\right)$ at $-68.81 \mathrm{ppm}$, attributed to the $\mathrm{CF}_{3}$. The assignments are consistent with previous literature report. ${ }^{33}$ Its ${ }^{13} \mathrm{C}$ NMR spectrum (Figure S5) displays a singlet at $167.28 \mathrm{ppm}$, attributed to the carbonyl group in $c$. The quartets at $135.50 \mathrm{ppm}\left({ }^{3} J_{\mathrm{CF}}=4.9 \mathrm{~Hz}\right), 130.99 \mathrm{ppm}\left({ }^{2} J_{\mathrm{CF}}=\right.$ $32.6 \mathrm{~Hz})$ and $121.18 \mathrm{ppm}\left({ }^{1} J_{\mathrm{CF}}=272.3 \mathrm{~Hz}\right)$ are assigned to $\mathrm{CH}_{2} \boldsymbol{d}, \boldsymbol{C}\left(\mathrm{CF}_{3}\right)(\mathrm{COOH}) \boldsymbol{b}$ and $\mathrm{CF}_{3} \boldsymbol{a}$, respectively. Similar signals were observed in $\mathrm{D}_{2} \mathrm{O}$ with the supplementary coupling ${ }^{2} J_{\mathrm{HH}}=0.5 \mathrm{~Hz}$ of the geminal protons of vinyl $\mathrm{CH}_{2}=($ Figures $\mathrm{S6}-7)$.

DiMAF. The identification of diMAF $(2 \mathrm{~m})$ was performed by analysing the mixture of MAF $(84 \%)$ and diMAF (16\%), with trace of triMAF, obtained from the reaction without any additive (Entry 1-Table 1), before MAF removal. The ${ }^{1} \mathrm{H}$ NMR spectrum (Figures S10-top) displays two quartets assigned to ethylenic hydrogens $\mathrm{CH}_{2}=\boldsymbol{d}^{1}$ at $6.76 \mathrm{ppm}\left({ }^{4} J_{\mathrm{HF}}=1.7 \mathrm{~Hz}\right)$ and at $6.51 \mathrm{ppm}\left({ }^{4} J_{\mathrm{HF}}=1.2 \mathrm{~Hz}\right)$. The doublet $\left({ }^{3} J_{\mathrm{HH}}=5.9 \mathrm{~Hz}\right)$ at $4.71 \mathrm{ppm}$ and the quartet $\left({ }^{3} \mathrm{JFF}_{\mathrm{HF}}=8.0 \mathrm{~Hz}\right)$ of triplets $\left({ }^{3} J_{\mathrm{HH}}=5.9 \mathrm{~Hz}\right)$ at $3.64 \mathrm{ppm}$, are assigned to $\mathrm{CH}_{2} \boldsymbol{d}^{2}$ and $\mathrm{CH} \boldsymbol{b}^{2}$, respectively. ${ }^{29} \mathrm{CF}_{3}$ group in $\mathrm{C}=\mathrm{C}\left(\mathrm{CF}_{3}\right)(\mathrm{COOH}) \boldsymbol{a}^{1}$ gives a doublet $\left({ }^{4} J_{\mathrm{FH}}=\right.$ $1.7 \mathrm{~Hz}$ ) of doublets $\left({ }^{4} \mathrm{~J}_{\mathrm{FH}}=1.2 \mathrm{~Hz}\right)$ at $-68.91 \mathrm{ppm}$, while that in $\mathrm{CH}_{2}-\mathrm{C}\left(\mathrm{CF}_{3}\right)(\mathrm{COOH}) \boldsymbol{a}^{2}$ affords a doublet 
$\left({ }^{3} J_{\mathrm{FH}}=8.1 \mathrm{~Hz}\right)$, because of its coupling with geminal hydrogens, at $-69.51 \mathrm{ppm}$ (Figures S10 -bottom).

On the ${ }^{13} \mathrm{C}$ NMR spectrum (Figure S11), the $-\mathrm{COO}-\boldsymbol{c}^{1}$ and $\boldsymbol{c}^{2}$ lead to signals at 170.41 and $160.77 \mathrm{ppm}$. The quartets at $134.46 \mathrm{ppm}\left({ }^{3} \mathrm{JFF}_{\mathrm{CF}}=5.0 \mathrm{~Hz}\right)$ and $130.69 \mathrm{ppm}\left({ }^{2} \mathrm{~J}_{\mathrm{CF}}=32.7 \mathrm{~Hz}\right)$ are assigned to $\mathrm{CH}_{2}=\boldsymbol{d}^{1}$ and $\mathrm{CH}_{2}=\boldsymbol{C}\left(\mathrm{CF}_{3}\right)(\mathrm{COO}) \boldsymbol{b}^{1}$, respectively. The $\mathrm{CH}_{2}=\mathrm{C}\left(\mathrm{CF}_{3}\right)(\mathrm{COO}) \boldsymbol{a}^{1}$ is represented by a quartet $\left({ }^{1} J_{\mathrm{CF}}=272.3\right.$ $\mathrm{Hz}$ ) at $121.18 \mathrm{ppm}$ which is totally overlapped with the corresponding carbon atom of the MAF monomer. The $\mathrm{CH}_{2}-\mathrm{CH}\left(\mathrm{CF}_{3}\right)(\mathrm{COO}) \boldsymbol{a}^{2}$ gives a quartet at $123.29\left({ }^{1} J_{\mathrm{CF}}=280.2 \mathrm{~Hz}\right)$. The quartets located at $60.23 \mathrm{ppm}\left({ }^{3} J_{\mathrm{CF}}=2.9 \mathrm{~Hz}\right)$ and $49.35 \mathrm{ppm}\left({ }^{2} J_{\mathrm{CF}}=28.6 \mathrm{~Hz}\right)$ are attributed to $\mathrm{CH}_{2} \boldsymbol{d}^{2}$ and $\mathrm{CH} \boldsymbol{b}^{2}$, respectively. ${ }^{29}$ These assignments are confirmed below in the analysis of the diMAF/triMAF mixture (Figures S12-14).

TriMAF. Within the same reaction (Entry 1-Table 1), after MAF removal by sublimation, a mixture of diMAF (67 \%) and triMAF (33 \%) was analysed. The spectra of triMAF exhibit all signals characteristic of the diMAF, and therefore the $\mathrm{CH}_{2} \mathrm{CH}\left(\mathrm{CF}_{3}\right) \mathrm{COOH}$ moiety is described hereafter. The ${ }^{1} \mathrm{H} N M R$ spectrum (Figure S12-top) displays a doublet $\left({ }^{4} J_{\mathrm{HF}}=5.9 \mathrm{~Hz}\right)$ of multiplets at $4.67 \mathrm{ppm}$ assigned to $\mathrm{CH}_{2}$ $\boldsymbol{d}^{3}$ and a quartet $\left({ }^{3} \mathrm{~J}_{\mathrm{HF}}=8.0 \mathrm{~Hz}\right)$ of triplets $\left({ }^{3} \mathrm{~J}_{\mathrm{HH}}=5.9 \mathrm{~Hz}\right)$ at $3.60 \mathrm{ppm}$ attributed to $\mathrm{CH} \boldsymbol{b}^{3}$. The multiplicity of the latter signal was determined thanks to ${ }^{1} \mathrm{H}\left\{{ }^{19} \mathrm{~F}\right\}$ NMR spectrum (Figure S12-bottom).

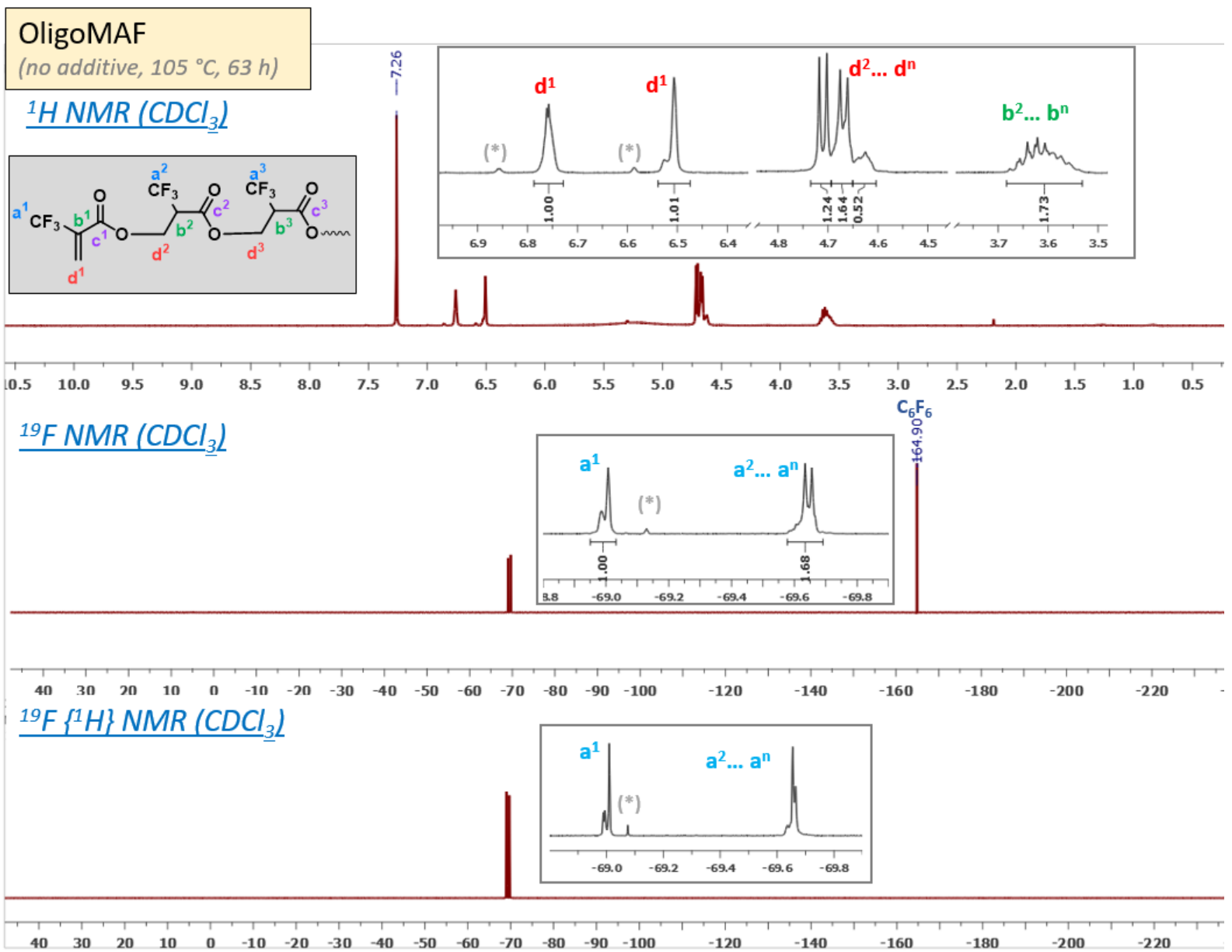


Figure $1:{ }^{1} \mathrm{H}$ (top), ${ }^{19} \mathrm{~F}$ (middle) and ${ }^{19} \mathrm{~F}\left\{{ }^{1} \mathrm{H}\right\}$ (bottom) NMR spectra, recorded in $\mathrm{CDCl}_{3}$, of oligoMAF obtained without additive, $105^{\circ} \mathrm{C}, 63 \mathrm{~h}$, after MAF removal (Entry $2-$ Table 1). DP $P_{n}=2.7$ was dertermined with both of ${ }^{1} \mathrm{H}$ and ${ }^{19} \mathrm{FNMR}$.

The ${ }^{19} \mathrm{~F}$ NMR spectrum (Figure $\mathrm{S} 13$ - bottom) shows the signal of $\mathrm{CF}_{3}$ end unit, $\mathrm{CH}_{2}=\mathrm{C}\left(\mathrm{CF}_{3}\right)(\mathrm{COO}) \boldsymbol{a}^{1}$ in triMAF, at $-68.89 \mathrm{ppm}$ as a doublet $\left({ }^{4} J_{\mathrm{FH}}=1.7 \mathrm{~Hz}\right)$ of doublets $\left({ }^{4} J_{\mathrm{FH}}=1.2 \mathrm{~Hz}\right)$ of doublets $\left(J_{\mathrm{FF}}=1.8 \mathrm{~Hz}\right)$, distinguished from the corresponding $\mathrm{CF}_{3}$ of diMAF. The $\mathrm{CF}_{3}$ of unit 3 gives a doublet $\left({ }^{3} \mathrm{FHH}_{\mathrm{FH}}=8.1 \mathrm{~Hz}\right)$ of doublets $\left(J_{\mathrm{FF}}=3.2 \mathrm{~Hz}\right)$ at $-69.56 \mathrm{ppm}$. Two signals involved $J_{\mathrm{FF}}$ were observed with weak intensities and will be discussed later. These assignments were achieved thanks to decoupled ${ }^{19} \mathrm{~F}\left\{{ }^{1} \mathrm{H}\right\}$ and ${ }^{19} \mathrm{~F}\left\{{ }^{1} \mathrm{H}\right\}\left\{{ }^{13} \mathrm{C}\right\}$ NMR spectra (Figure S13 - top) which gave the same profile. It is worth noting that the elementary doublets $\left(J_{\mathrm{FF}}=1.8 \mathrm{~Hz}\right.$ and $\left.J_{\mathrm{FF}}=3.2 \mathrm{~Hz}\right)$, due to the through-space coupling that is explained further, were not present in diMAF.

Distinct signals were also observed in the ${ }^{13} \mathrm{C}$ NMR spectrum (Figure S14), as the $\mathrm{CH}_{2}=\boldsymbol{d}^{\boldsymbol{1}}$ and $\mathrm{CH}_{2}=\boldsymbol{C}\left(\mathrm{CF}_{3}\right)(\mathrm{COO}) \boldsymbol{b}^{1}$ of triMAF are represented by two quartets at $134.60\left({ }^{3} \mathrm{~J}_{\mathrm{CF}}=5.0 \mathrm{~Hz}\right)$ and 130.55 ppm $\left({ }^{2} J_{C F}=32.9 \mathrm{~Hz}\right)$, respectively, slightly shifted from the corresponding signals of diMAF. The MAF unit 3 gives two peaks at 170.03 and $164.15 \mathrm{ppm}$, attributed to $\mathrm{COO} c^{3}$, a quartet at $123.16 \mathrm{ppm}\left({ }^{1} J_{\mathrm{CF}}\right.$ $=286.2 \mathrm{~Hz})$ to $\mathrm{CH}_{2}=\mathrm{C}\left(C_{3}\right)(\mathrm{COO}) \boldsymbol{a}^{3}$, quartet $\left({ }^{3} J_{\mathrm{CF}}=2.4 \mathrm{~Hz}\right)$ at $60.63 \mathrm{ppm}$ to $\mathrm{CH}_{2} \boldsymbol{d}^{3}$ and two quartets of doublets at $49.32 \mathrm{ppm}\left({ }^{2} J_{\mathrm{CF}}=28.5 \mathrm{~Hz}, J_{\mathrm{FF}}=2.2 \mathrm{~Hz}\right)$ and $49.17 \mathrm{ppm}\left({ }^{2} J_{\mathrm{CF}}=28.7 \mathrm{~Hz}, J_{\mathrm{FF}}=2.9 \mathrm{~Hz}\right)$ assigned to $\mathrm{CH} \boldsymbol{b}^{3}{ }^{29}$

The coupling atoms of previously mentionned $J_{\mathrm{FF}}$ was confirmed because the corresponding doublets were observed on both ${ }^{19} \mathrm{~F}\left\{{ }^{1} \mathrm{H}\right\}$ and ${ }^{19} \mathrm{~F}\left\{{ }^{1} \mathrm{H}\right\}\left\{{ }^{13} \mathrm{C}\right\}$ NMR spectra (Figure S13-top), which have the same profile. Similar coupling constants are also noted in the ${ }^{13} \mathrm{C}$ NMR spectrum (Figure S14). It indicates likely two fluorine atoms from two consecutive $\mathrm{CF}_{3}$ groups of oligoMAF, separated by 8 chemical bonds. Indeed, according to the literature, ${ }^{34}$ the values 2.2 and $2.9 \mathrm{~Hz}$ should correspond to the coupling constant of ${ }^{n} J_{F F}$ with $n=5-7$, which are not found in the oligoMAF structure. As reported by Foris and Roche, ${ }^{35,36}$ direct through bond ${ }^{8} J_{\mathrm{FF}}$ coupling can be eliminated as these authors found value up to only 2 and because of the presence of the $\mathrm{O}$ atoms between two $\mathrm{CF}_{3}$ groups. ${ }^{37,38}$ Indirect through space coupling seems therefore to be a reliable explanation.

OligoMAF . The oligoMAF obtained from the reaction without additive, heated at $105{ }^{\circ} \mathrm{C}$ for $63 \mathrm{~h}$ (Entry 2- Table 1) after MAF removal was characterised by NMR spectroscopy. The ${ }^{1} \mathrm{H}$ NMR spectrum (Figure 1 - top) shows multiplet centered at $6.76 \mathrm{ppm}$ and $6.51 \mathrm{ppm}$ attributed to ethylenic protons $\mathrm{CH}_{2}=\boldsymbol{d}^{1}$. The complex multiplets ranging from 4.72 to $4.57 \mathrm{ppm}$ and from 3.69 to $3.59 \mathrm{ppm}$ are assigned to $\mathrm{CH}_{2} \boldsymbol{d}^{2} \ldots \boldsymbol{d}^{n}$ and- $\mathrm{CH}\left(\mathrm{CF}_{3}\right) \mathrm{COOH} \boldsymbol{b}^{2} . . . \boldsymbol{b}^{n}$ moities of the oligomers, respectively. As the adjacent $\mathrm{CH}\left(\mathrm{CF}_{3}\right)$ group bears an asymetric carbon atom, both protons in such a methylene group are non-equivalent. The ${ }^{19} \mathrm{~F}$ and ${ }^{19} \mathrm{~F}\left\{{ }^{1} \mathrm{H}\right\}$ NMR spectra (Figure $1-$ middle and bottom) display $\mathrm{C}=\mathrm{C}\left(\mathrm{CF}_{3}\right) \boldsymbol{a}^{\mathbf{1}}$ multiplet centered at $-68.91 \mathrm{ppm}$ and $-\mathrm{CH}\left(\mathrm{CF}_{3}\right) \mathrm{COO}-\boldsymbol{a}^{2} . . . a^{n}$ signal centered at $-69.51 \mathrm{ppm}$. 
Concerning the ${ }^{13} \mathrm{C}$ NMR spectroscopy (Figure 2), the singlets found from 160.7 to $169.7 \mathrm{ppm}$ are attributed to $\mathrm{COO} \boldsymbol{c}^{1} . . . n^{n}$ while those from 134.3 to $135.5 \mathrm{ppm}$ are assigned to $\mathrm{CH}_{2} \boldsymbol{d}^{1}$. Quaternary carbon in $\mathrm{CH}_{2}=\boldsymbol{C}\left(\mathrm{CF}_{3}\right)(\mathrm{COO}) \boldsymbol{b}^{1}$ gives quartets $\left({ }^{2} J_{\mathrm{CF}} \approx 33 \mathrm{~Hz}\right)$ centered at $130.5 \mathrm{ppm}$. Quartet $\left({ }^{1} J_{\mathrm{CF}}=\right.$ $272.4 \mathrm{~Hz})$ at $121.14 \mathrm{ppm}$ is attributed to $\mathrm{CF}_{3} \boldsymbol{a}^{1}$ while the quartet $\left({ }^{1} J_{\mathrm{CF}}=280.2 \mathrm{~Hz}\right)$ of multiplets at $c a$. $123 \mathrm{ppm}$ is assigned to $\mathrm{CF}_{3} \boldsymbol{a}^{2} \ldots \boldsymbol{a}^{n}$. Signals from 60.8 to $60.0 \mathrm{ppm}$ and from 49.8 to $48.5 \mathrm{ppm}$ are attributed to $d^{2} \ldots d^{n}$ and $b^{2} \ldots b^{n}$, respectively.

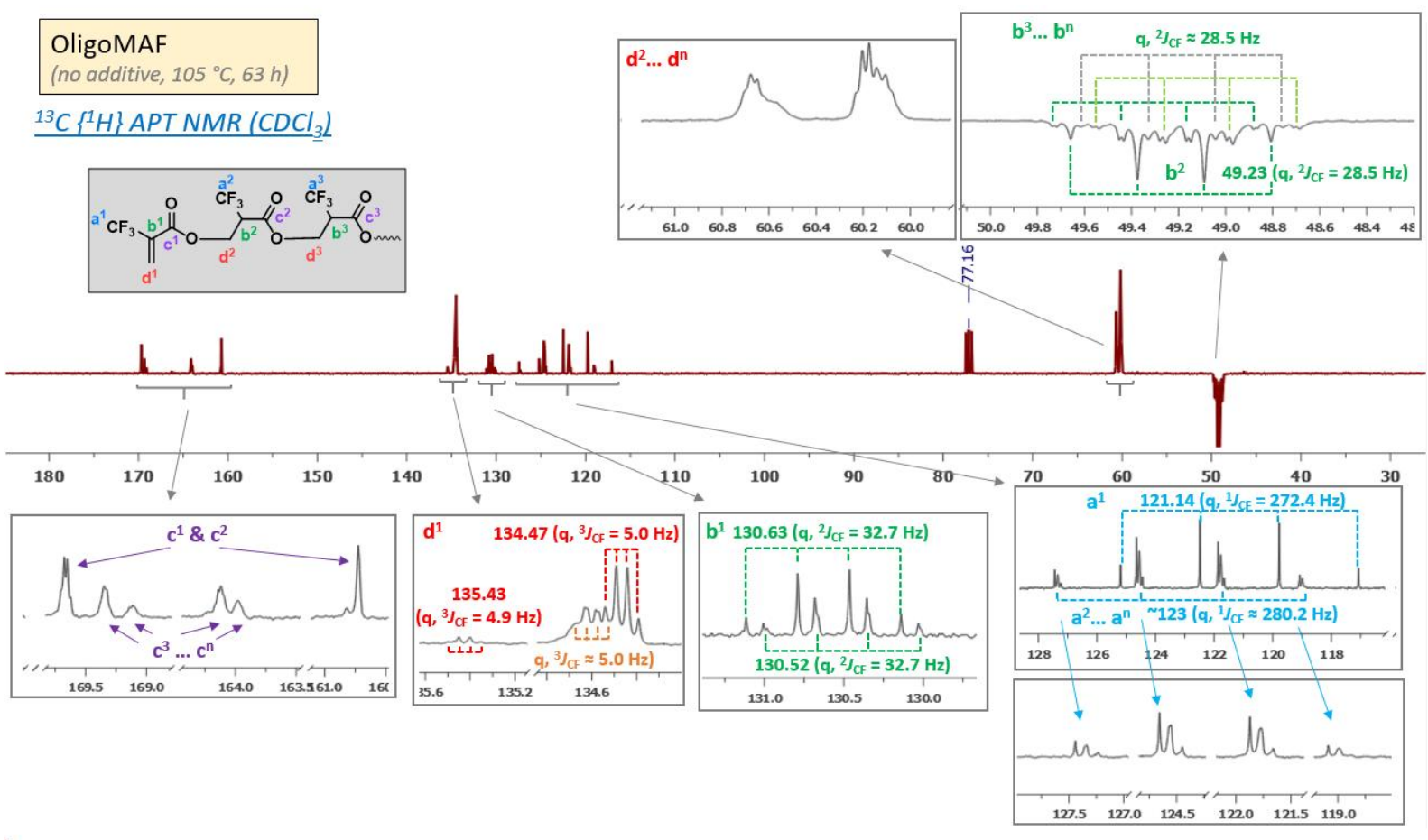

Figure 2: ${ }^{13} \mathrm{C}\left\{{ }^{1} \mathrm{H}\right\}$-APT NMR spectrum, recorded in $\mathrm{CDCl}_{3}$, of oligoMAF (obtained without additive, $105{ }^{\circ} \mathrm{C}, 63 \mathrm{~h}$, after MAF removal) (Entry 2-Table 1)

The $2 \mathrm{D}{ }^{1} \mathrm{H}-{ }^{13} \mathrm{C}$ HMQC NMR spectrum (Figure 3) confirms the assignments. Both protons in the methylene group $\boldsymbol{d}^{1}$ signals, centered at 6.76 and $6.51 \mathrm{ppm}$ in the ${ }^{1} \mathrm{H}$ NMR spectrum, are connected to the corresponding signal of the carbon atom, found at $134.6 \mathrm{ppm}$ in the ${ }^{13} \mathrm{C}$ NMR spectrum. Multiplets at 4.75-4.61 ppm and 3.69-3.52 ppm, are connected to those at 60.81-59.99 ppm and 49.76-48.57 ppm, showing the correlations for $\mathrm{CH}_{2} \boldsymbol{d}^{2} \ldots \boldsymbol{d}^{n}$ and $\mathrm{CH} \boldsymbol{b}^{2} . . \boldsymbol{b}^{n}$ moities, respectively. These clues evidence that the oxa-Michael reaction occured instead of a polymerisation by the opening of the $\mathrm{C}=\mathrm{C} \pi$ bond.

The $2 \mathrm{D}{ }^{1} \mathrm{H}-{ }^{19} \mathrm{~F}$ and ${ }^{13} \mathrm{C}^{-19} \mathrm{~F}$ NMR spectra were also recorded as evidences of these assignments. The HeteroCOSY ${ }^{1} \mathrm{H}^{19}{ }^{\mathrm{F}}$ spectrum (Figure S16) shows the correlations of $\mathrm{F}$ atoms with the nearest $\mathrm{H}$ ones, i.e. $\mathrm{CH}_{2}=\boldsymbol{d}^{1} / \mathrm{CF}_{3} \boldsymbol{a}^{1}$ and $\mathrm{CH} \boldsymbol{b}^{2} \ldots \boldsymbol{b}^{n} / \mathrm{CF}_{3} \boldsymbol{a}^{1} \ldots \boldsymbol{a}^{n}$. The signals of these protons are intense on the one dimension spectrum $\left({ }^{1} \mathrm{H}\right)$. Signal at $4.6 \mathrm{ppm}$ of further protons as $\mathrm{CH}_{2} \boldsymbol{d}^{2} \ldots \boldsymbol{d}^{n}$, compared to $\mathrm{CH} \boldsymbol{b}^{2} \ldots \boldsymbol{b}^{n}$, have weak intensity resulting from weak correlation. The gHSQC spectrum (Figure S17) highlights 
only ${ }^{1} J_{\mathrm{CF}}$, corresponding to $\mathrm{CF}_{3} \boldsymbol{a}^{1}$ and $\boldsymbol{a}^{2} \ldots \boldsymbol{a}^{n} .{ }^{1} \mathrm{H}$ decoupling is applied during the whole sequence and, therefore, only the signals of the $\mathrm{C}$ atoms that have ${ }^{1} J_{\mathrm{CF}}$ are displayed on the one dimension spectrum $\left({ }^{13} \mathrm{C}\right)$.

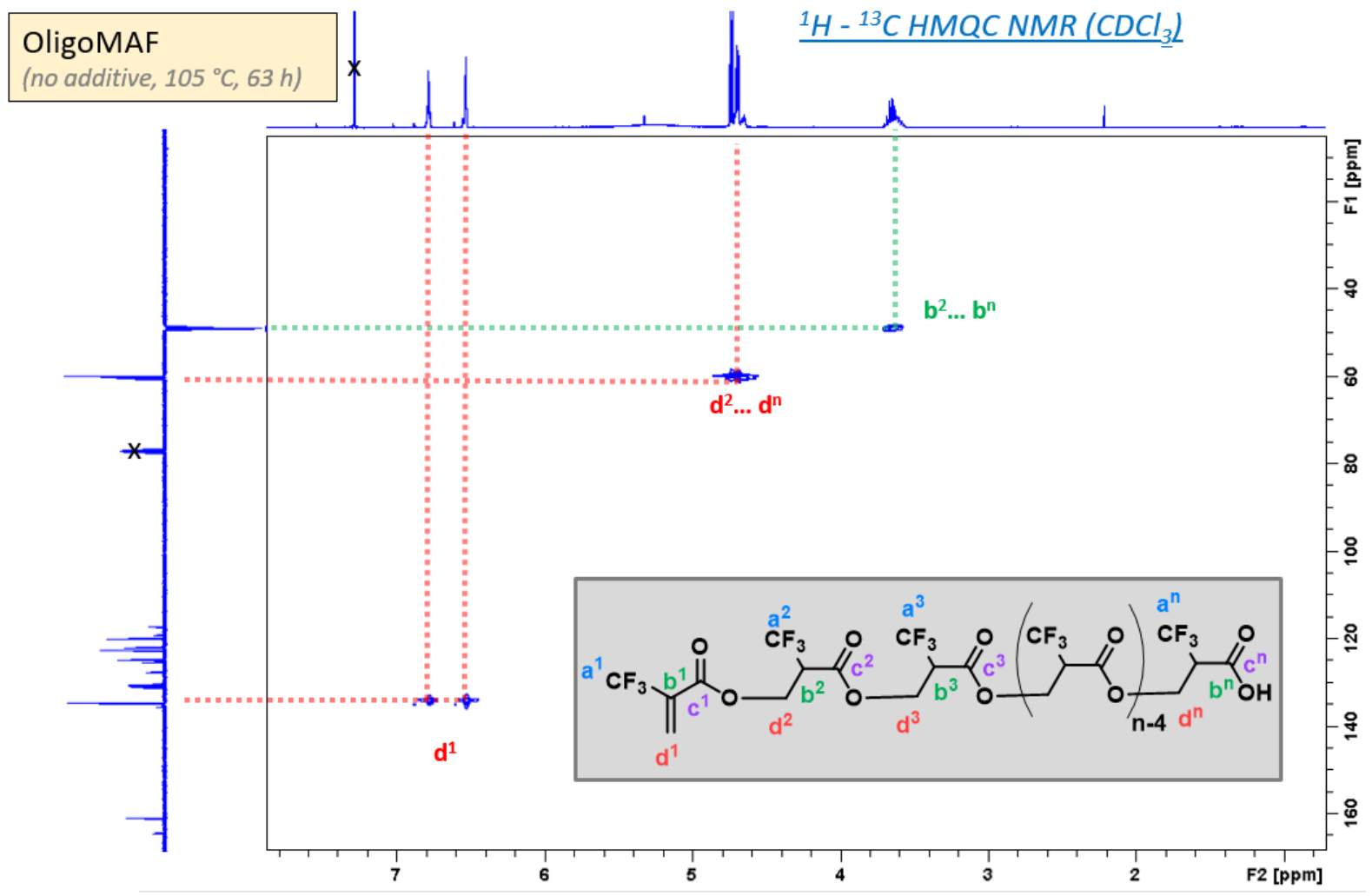

Figure $3: 2 D^{1} \mathrm{H}^{13}{ }^{13} \mathrm{CHMQC} \mathrm{NMR} \mathrm{spectrum,} \mathrm{recorded} \mathrm{in} \mathrm{CDCl}_{3}$, of oligoMAF (obtained without additive, $105{ }^{\circ} \mathrm{C}, 63 \mathrm{~h}$ ) after MAF removal (Entry 2 - Table 1). The one-dimensional spectra are plotted at the top $\left({ }^{1} \mathrm{H}\right)$ and left $\left({ }^{13} \mathrm{C}\left\{{ }^{1} \mathrm{H}\right\}\right.$-APT) of the $2 \mathrm{D}$ plots

Based on these above NMR characterisations, the formulas for MAF conversions and average degrees of oligomerisation, $\mathrm{DP}_{\mathrm{n}}$, can be proposed. As each unit in oligomers has distinguished $\mathrm{CH}$ (vinyl $=\mathrm{CH}$ or $-\mathrm{CH}\left(\mathrm{CF}_{3}\right) \mathrm{COOH}$ moities) and $\mathrm{CF}_{3}\left(\mathrm{C}=\mathrm{C}\left(\mathrm{CF}_{3}\right)\right.$ or $\left.-\mathrm{CH}\left(\mathrm{CF}_{3}\right) \mathrm{COO}-\right)$, MAF conversion can be calculated with the formulas (1) or (2) using integrals from the characteristic signals in ${ }^{1} \mathrm{H}$ or ${ }^{19} \mathrm{~F}$ NMR spectra of the reaction mixtures before work-up, respectively (Figure 4 - top). For phosphinescatalysed reactions, see ESI.

Conv. $(\mathrm{MAF})(\%)=\frac{\int_{6.7}^{6.8} \mathrm{CH}(\text { oligomers })+\int_{3.6}^{3.7} \mathrm{CH}(\text { oligomers })}{\int_{6.7}^{6.8} \mathrm{CH}(\text { oligomers })+\int_{3.6}^{3.7} \mathrm{CH}(\text { oligomers })+\int_{6.8}^{6.9} \mathrm{CH}(\text { unreacted } M A F)} \times 100$

Conv. $(\mathrm{MAF})(\%)=\frac{\int_{-69.0}^{-68.9} C F_{3}(\text { oligomers })+\int_{-69.6}^{-69.5} C F_{3}(\text { oligomers })}{\left.\int_{-69.0}^{-68.9} C F_{3} \text { (oligomers }\right)+\int_{-69.6}^{-69.5} C F_{3}(\text { oligomers })+\int_{-69.1}^{-69.0} C F_{3}(\text { unreacted MAF })} x 100$ 
For the same reason, $\mathrm{DP}_{\mathrm{n}}$ can be also determined in two ways (equations 3 and 4) :

$$
\begin{aligned}
& \mathrm{DP}_{\mathrm{n}}=\frac{\int_{6.7}^{6.8} C H(\text { oligomers })+\int_{3.6}^{3.7} C H(\text { oligomers })}{\int_{6.7}^{6.8} C H(\text { oligomers })}=1+\frac{\int_{3.6}^{3.7} C H(\text { oligomer })}{\int_{6.7}^{6.8} C H(\text { oligomer })} \\
& \mathrm{DP}_{\mathrm{n}}=\frac{\int_{-69.0}^{-68.9} C F_{3}(\text { oligomers })+\int_{-69.1}^{-69.0} C F_{3}(\text { oligomer })}{\int_{-69.0}^{-68.9} C F_{3}(\text { oligomer })}=1+\frac{\int_{-69.1}^{-69.0} C F_{3}(\text { oligomers })}{\int_{-69.0}^{-68.9} C F_{3}(\text { oligomer })}
\end{aligned}
$$

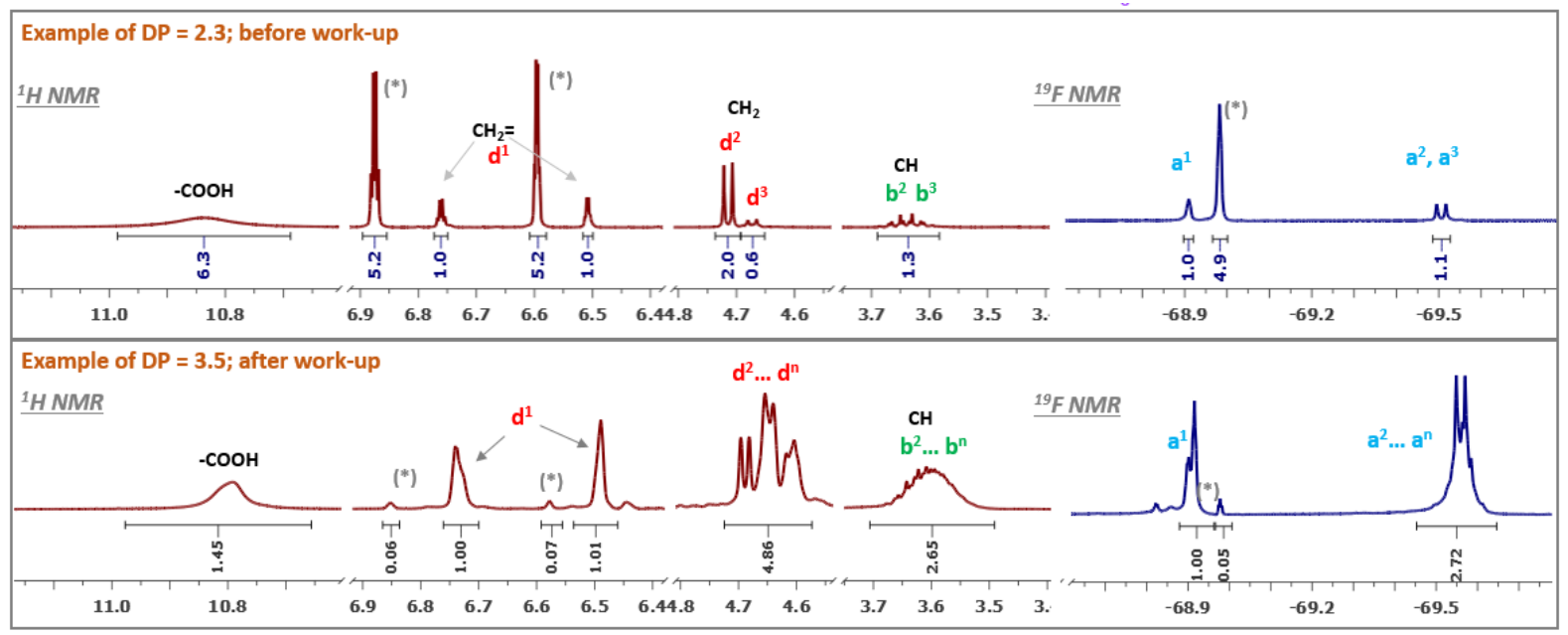

Figure $4:{ }^{1} \mathrm{H}$ (left) and ${ }^{19} \mathrm{~F}$ (right) NMR spectra, recorded in $\mathrm{CDCl}_{3}$, of the product resulting from the oligomerisation of MAF by oxa-Michael addition in case of $D P_{n}=2.3$ (top) and $D P_{n}=3.7$ (bottom) (Entries 1 \& 6 - Table 1); starred signals represent unreacted MAF

\section{Fourier transform infrared (FTIR) spectroscopy}

IR spectrum of MAF (Figure S9) displays a large band centered at $3500 \mathrm{~cm}^{-1}$, corresponding to $\mathrm{O}-\mathrm{H}$ (in $\mathrm{COOH}$ ) and $\mathrm{C}\left(\mathrm{sp}^{2}\right)-\mathrm{H}$ of ethylenic $\mathrm{CH}_{2}=$ end-group. $\mathrm{C}=\mathrm{O}$ (in $\mathrm{COOH}$ ) frequency at $1720 \mathrm{~cm}^{-1}$ and that of $\mathrm{C}-\mathrm{F}$ at 1145 and $1102 \mathrm{~cm}^{-1}$ have high intensities because of the high polarity of the bonds. $\mathrm{C}=\mathrm{C}$ bands with medium intensities were also observed at 1635 and $1407 \mathrm{~cm}^{-1}$.

The IR spectrum of oligoMAF (Figure S20 - red spectrum) exhibits a wide band with weak intensity centered at $2977 \mathrm{~cm}^{-1}$, corresponding to the vanishing of $\mathrm{O}-\mathrm{H}(\mathrm{COOH})$ and $\mathrm{C}\left(\mathrm{sp}^{2}\right)-\mathrm{H}$ and also the presence of $\mathrm{C}\left(\mathrm{sp}^{3}\right)-\mathrm{H}$. The $\mathrm{C}=\mathrm{O}$ (ester) band at $1742 \mathrm{~cm}^{-1}$ is slightly shifted compared to that of $\mathrm{C}=\mathrm{O}(\mathrm{COOH})$ of MAF. Weaker intensity was observed at the $\mathrm{C}=\mathrm{C}$ bands at 1635 and $1407 \mathrm{~cm}^{-1}$. Stronger signals, compared to those in IR spectrum of MAF, observed in $1300-900 \mathrm{~cm}^{-1}$ window, are assigned to formed $\mathrm{C}-\mathrm{C}$ and $\mathrm{C}-\mathrm{O}-\mathrm{C}=\mathrm{O}$ bonds. All the described frequencies are in stretching mode.

\section{Gas chromatography coupled with mass spectrometry (GC/MS)}

The GC spectrum of MAF shows a peak at a retention time $\left(t_{R}\right)$ of 6.77 min (Figure S8). The GC spectrum of example 2 - Table 1 (Figure 5 - top) exhibits two peaks: that at $t_{R}=10.18$ min correponds 
to diMAF while the one at $t_{R}=11.95$ min to triMAF and longer oligoMAFs, confirmed by GC analysis of diMAF/triMAF mixture (Figure S15). The mass spectroscopy spectra of diMAF and triMAF/oligoMAF (Figure 5 - two middle spectra) display $\mathrm{m} / \mathrm{z}=123$, corresponding to $\mathrm{CH}_{2}=\mathrm{C}\left(\mathrm{CF}_{3}\right) \mathrm{COO}^{\circ}$ fragment, as the base peak.

Based on the obtained $\mathrm{m} / \mathrm{z}$ values, two decomposition mechanisms of diMAF can be proposed (Scheme 3). Pathway 1 starts with the cleavage of the ester $\mathrm{C}-\mathrm{O}$ bond, giving $\mathrm{C}_{4} \mathrm{H}_{4} \mathrm{~F}_{3} \mathrm{O}_{3}{ }^{\circ}(\mathrm{m} / \mathrm{z}=157)$ fragment. The subsequent fragmentations of $\mathrm{O}$ atom and $-\mathrm{COOH}$ group afford $\mathrm{C}_{4} \mathrm{H}_{4} \mathrm{~F}_{3} \mathrm{O}_{2}{ }^{*}(\mathrm{~m} / \mathrm{z}=141)$ and $\mathrm{CHO}_{2}{ }^{\circ}(\mathrm{m} / \mathrm{z}=45)$, respectively. The second pathway separates $2 \mathrm{MAF}$ units and leads to $\mathrm{C}_{4} \mathrm{H}_{2} \mathrm{~F}_{3} \mathrm{O}_{2}{ }^{\circ}(\mathrm{m} / \mathrm{z}=139)$. The ester $\mathrm{C}-\mathrm{O}$ bond is then broken, releasing $\mathrm{CH}_{2}=\mathrm{C}\left(\mathrm{CF}_{3}\right) \mathrm{CO}^{\bullet}(\mathrm{m} / \mathrm{z}=123)$. Two final fragmentations give $\mathrm{C}_{3} \mathrm{H}_{2} \mathrm{~F}_{3}{ }^{\circ}(\mathrm{m} / \mathrm{z}=95)$ and $\mathrm{CF}_{3}{ }^{*}(\mathrm{~m} / \mathrm{z}=69)$. In addition, decarboxylation of $\mathrm{M}$ leads to $\mathrm{m} / \mathrm{z}=235$ (decomposition 3 ).
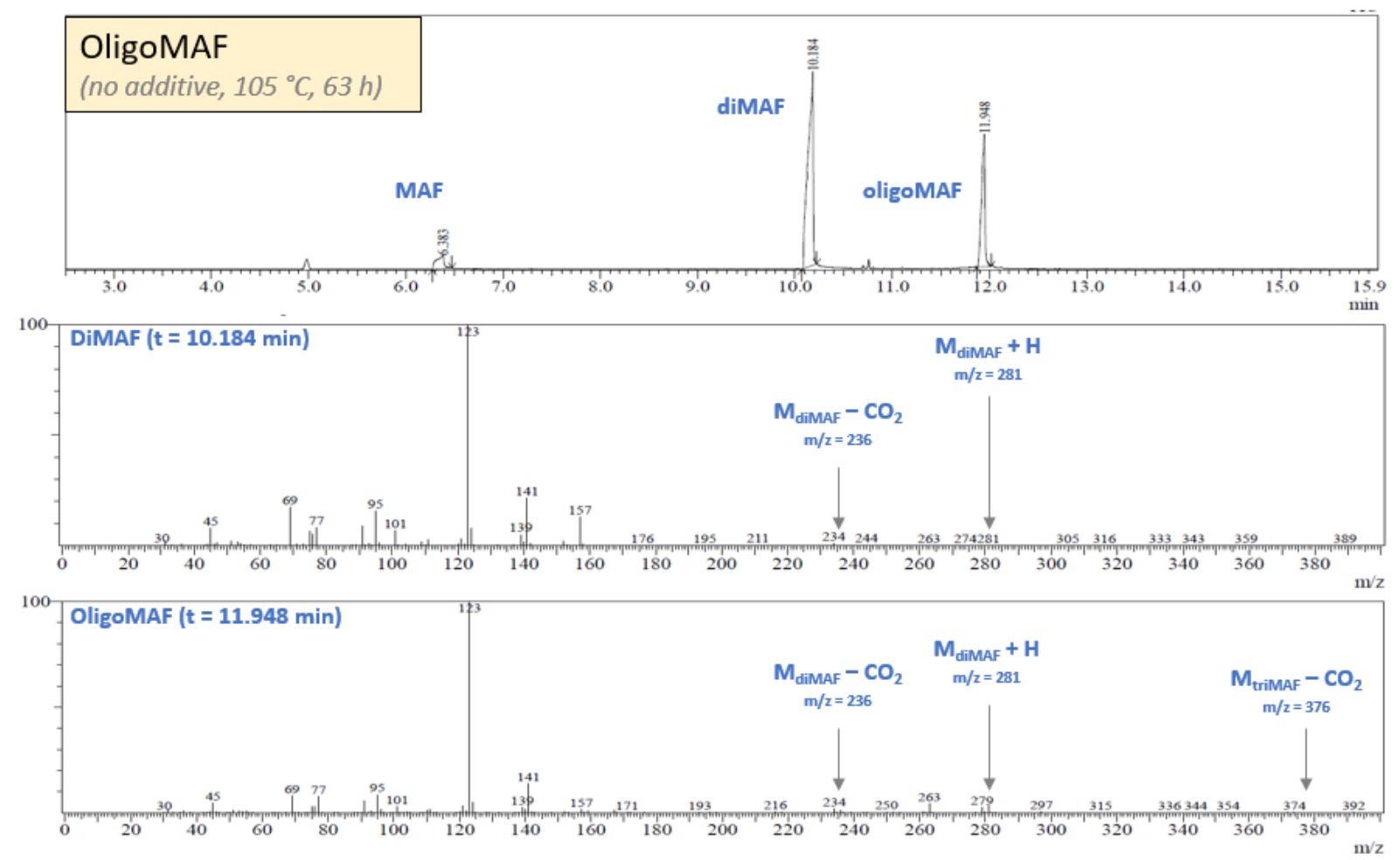

Figure 5 : GC/MS spectra of oligoMAF mixture (Entry 2 - Table 1) 


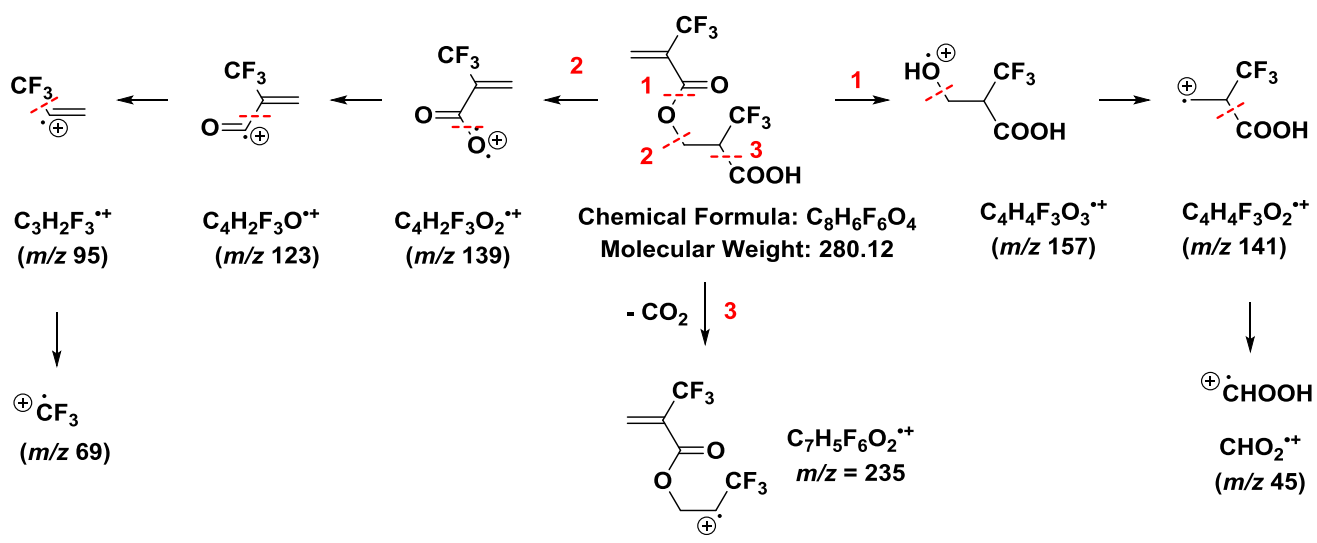

Scheme 3 : Proposed fragmentation pathways based on the $\mathrm{m} / \mathrm{z}$ values given by GC/MS (Entry 2 - Table 1)

OligoMAF, obtained in presence of diisopropylethylamine (DIPEA) (Entry 9-Table 1), was analysed by MALDI-TOF spectrometry. The positive reflectron spectrum (Figure 6) exhibits two signal series with unsymmetric Gaussian shape distribution. The first series, marked in green is assigned to [OligoMAF$\mathrm{Na}]^{+}$with $m / z=140 y+23$ and the mass difference corresponding to a MAF unit $(m / z=140)$, ranging between $m / z=583\left(D_{4}\right)$ and $m / z=2263\left(D_{16}\right)$. The distribution was centered on a $D_{6}$ chain at $m / z$ $=863$, the formula of which was determined as $\mathrm{CH}_{2}=\mathrm{C}\left(\mathrm{CF}_{3}\right) \mathrm{COOCH}_{2}\left[\mathrm{CH}\left(\mathrm{CF}_{3}\right) \mathrm{COOCH}_{2}\right]_{4} \mathrm{CH}\left(\mathrm{CF}_{3}\right) \mathrm{COOH}$ from isotopic distribution (Figure S21). $M_{n}$ and $M_{w}$ are 975 and 1083, respectively, leading to a dispersity of 1.1. The MS-MS analysis of $723 \mathrm{~m} / \mathrm{z}$ fragment gave similar profile as in case of oligoMAF obtained without additive (Entry 9-Table 1 and Figure S22).

Matrix-Assisted Laser Desorption Ionisation (MALDI-TOF) spectrometry.

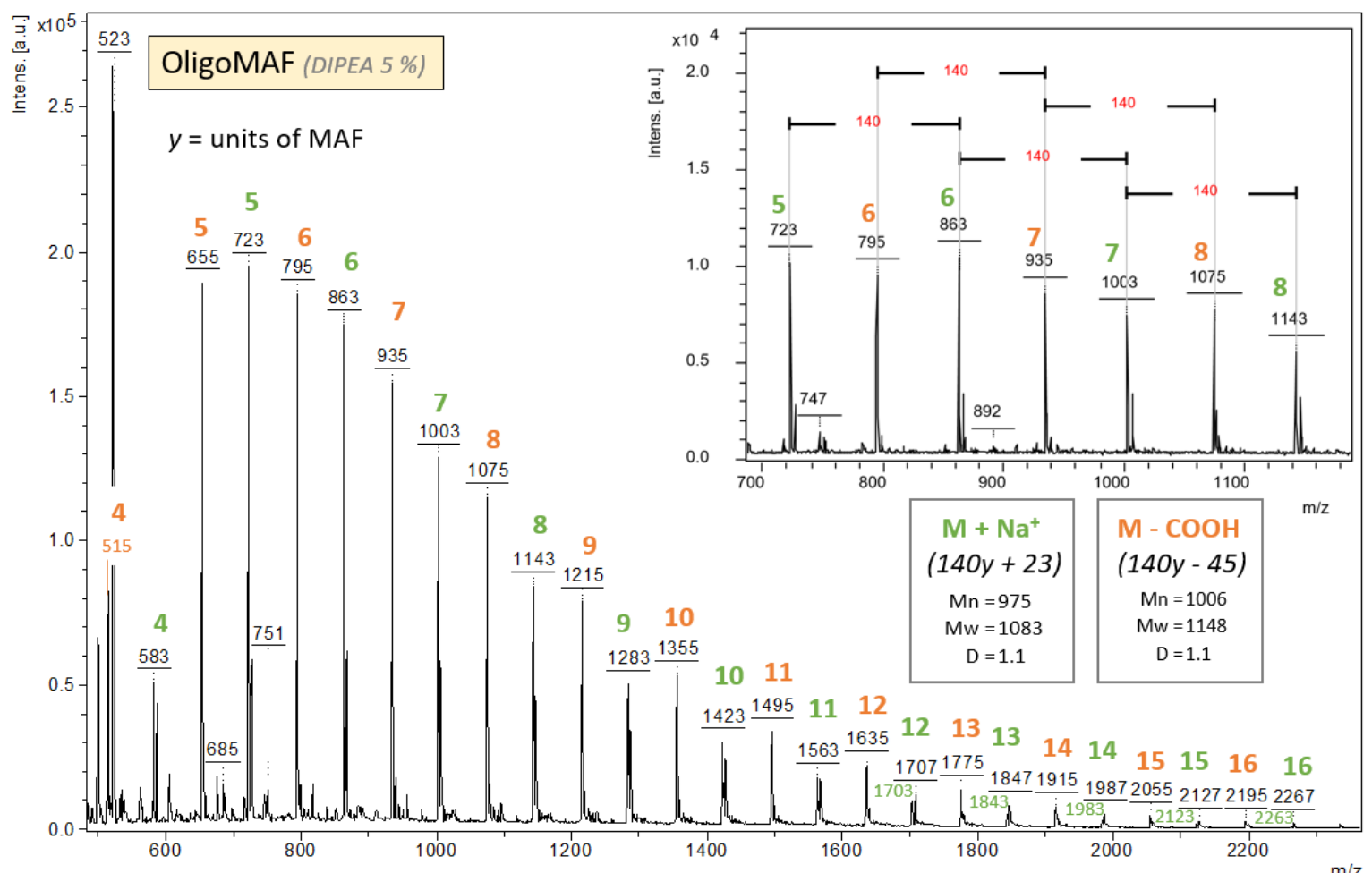


Figure 6: MALDI-TOF mass positive reflectron spectrum with expansion from 850 and $1090 \mathrm{~m} / \mathrm{z}$ with Nal and trans-2-[3-(4tertbutylphenyl)-2-methylprop-2-enylidene]malononitrile (DCTB) as the matrix (Entry 9-Table 1)

In the second series, marked in orange (Figure 6), all signals display quasi the same intensity as those of the green series. This probably indicated that all signals of the green distribution have lost some fragment. Indeed, after loosing a sodium atom, further $\mathrm{CO}_{2} \mathrm{H}$ end-group was also removed (Figure 7), probably resulted from the presence of DIPEA trace in the sample. The green series is then attributed to [OligoMAF-COOH] ${ }^{+}$, with the formula : $m / z=140 y-45$. Its distribution is centered on a $m / z=975$ $\left(D_{6}\right)$ and ranging between $m / z=655\left(D_{4}\right)$ and $m / z=2195\left(D_{16}\right)$. Average $M_{n}$ and $M_{w}$ are 1006 and 1148 , respectively, affording a dispersity of 1.1 . MS-MS analysis of $935 \mathrm{~m} / z\left(\mathrm{DP}_{7}\right)$ fragment (Figure S23) shows a cascade of MAF units (140) and, its isotopic distibution was also supplied.

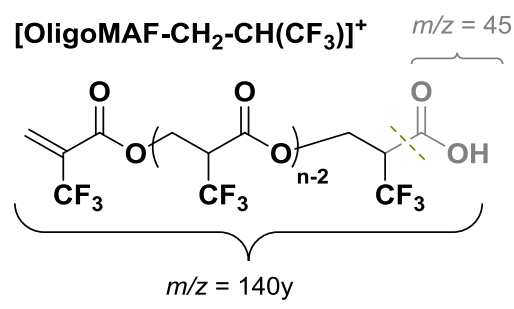

Figure 7: OligoMAF - COOH corresponding to $(140 y-45)$ series, where y is the MAF number

Another series of signals of small intensity next to the former one with $m / z=140 y+23+4$ is also observed but no explaination could be provided so far. OligoMAF obtained without additive (Entry 2Table 1) was also analysed and gave coherent results which are described in ESI (Figures S18-S19, Table S1).

\section{Thermogravimetric analysis (TGA)}

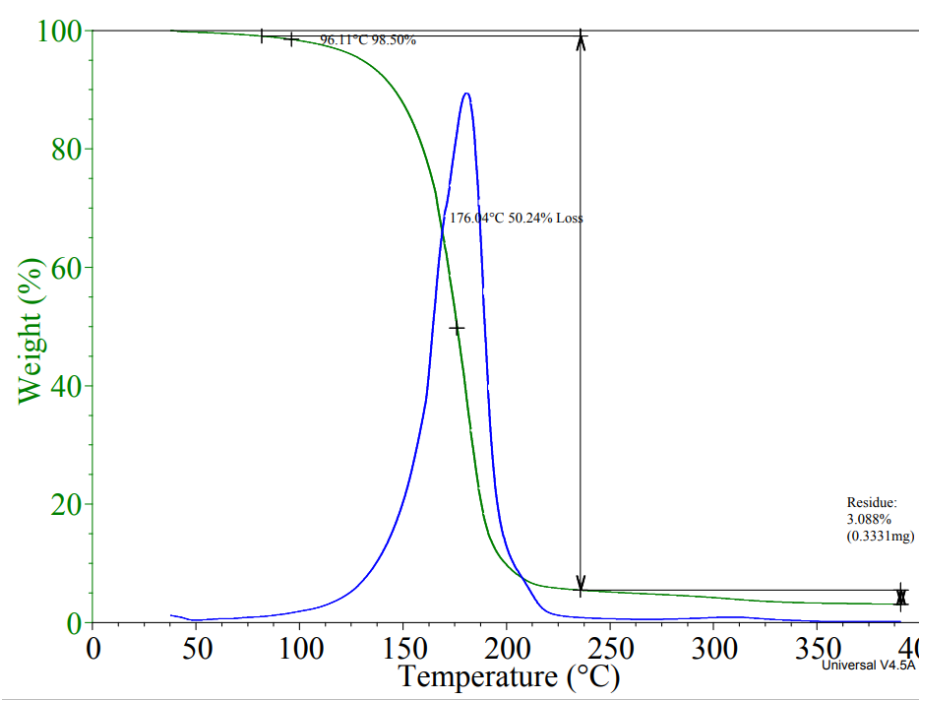

Figure 8: TGA thermogram and its derivative of oligo(MAF) under nitrogen (Entry 9-Table 1)

The thermal stability of oligoMAF was studied by thermogravimetric analysis (TGA) under $N_{2}$. 
Thermogram of oligoMAF (Figure 8) exhibits one step-degradation from $96{ }^{\circ} \mathrm{C}(1.5 \%$ loss) and $50 \%$ loss at $176{ }^{\circ} \mathrm{C}$. This degradation temperature is lower than that of non-fluorinated esters from acrylic acid that occurs in $250-300{ }^{\circ} \mathrm{C}$ range, ${ }^{9}$ or those from diols and diacids in $220-230{ }^{\circ} \mathrm{C}$ range. ${ }^{1}$ The electron-withdrawing $\mathrm{CF}_{3}$ group may induce some electronic effect to favor a faster degradation in addition to low molar mass of oligoMAF. Furthermore, it is known that depolymerisation occurs by unzipping from the $\mathrm{COOH}$ end group that first undergoes a decarboxylation. ${ }^{39}$

\section{Differential scanning calorimetry (DSC)}

The glass transition temperatures $\left(T_{g}\right)$ of oligoMAF was determined by DSC. The thermograms of which (Figures S29 - S30) exhibit a single $T_{g}$ : that of low molar mass diMAF (Entry 1 - Table 1 ) was $59{ }^{\circ} \mathrm{C}$ while oligoMAF obtained with DIPEA (Entry 9 -Table 1) has a $\mathrm{T}_{\mathrm{g}}$ of $-46^{\circ} \mathrm{C}$.

\section{Water contact angle (WCA)}

The surface properties of oligoMAF were assessed by means of water contact angle measurements (Figure 9 and Table S2). A glass substrate was coated by casting with oligoMAF (Entry 11-Table 1) that was first dissolved in dichloromethane and spread onto glass. A hydrophobic character was noted in the first 12 seconds. As expected, in contrast to polyacrylates bearing $\mathrm{C}_{8} \mathrm{~F}_{17}$ side groups, ${ }^{40,41}$ the oligoMAF does not display so high hydrophobic properties, probably limited by the presence of hydrophilic ester and carboxylic end groups.

$0 \mathrm{~s}$

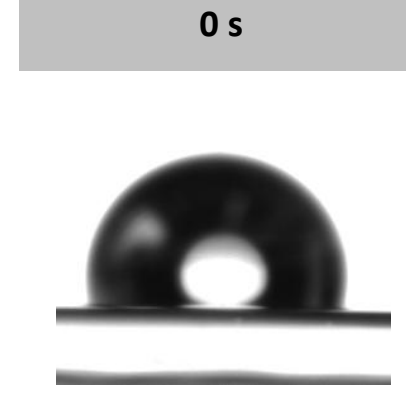

$107.0^{\circ}$

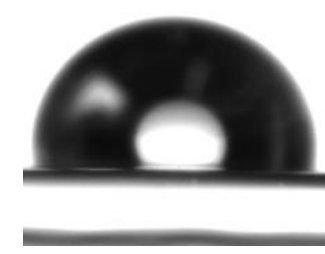

$101.5^{\circ}$

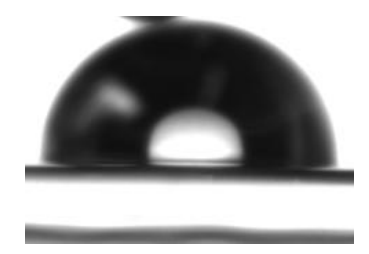

$98.4^{\circ}$
$12 \mathrm{~s}$

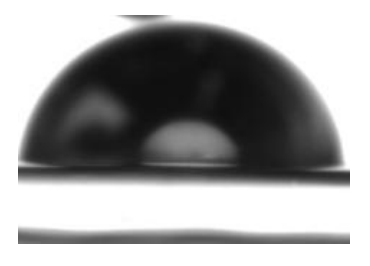

$93.4^{\circ}$

Figure 9: Water contact angles on oligoMAF obtained with $\mathrm{P}\left(\mathrm{C}_{6} \mathrm{H}_{11}\right)_{3}$ (Entry 11 - Table 1) coated onto a glass substrate at different intervals of time.

\subsection{Additives screening}

The second part of this section aims at optimising such a reaction according to radical, basic or acidic conditions and the results are listed in Table 1. First, without any additive, heating MAF at $95{ }^{\circ} \mathrm{C}$ for $24 \mathrm{~h}$ afforded oligoMAF in $15 \%$ yield in low molar mass $\left(D_{\mathrm{n}}=2.3\right)$ (Entry 1-Table 1$)$. MAF conversion $(66 \%)$ and propagation $\left(\mathrm{DP}_{\mathrm{n}}=2.6\right)$ increased with reaction temperature $\left(105^{\circ} \mathrm{C}\right)$ and time $(63 \mathrm{~h})$ (Entry 2 - Table 1). However, using toluene as solvent did not enhance these features (Entry 3 Table 1). Then, various additives were used and our interest was to study the influence of radical, 
basic or acidic species on the MAF conversion and $D P_{n}$.

Table 1 : Additives screening and experimental conditions for the oligomerisation of MAF by oxa-Michael addition

\begin{tabular}{|c|c|c|c|c|c|}
\hline Entry & $\begin{array}{l}\text { Additive } \\
\text { type }\end{array}$ & Conditions $^{a}$ & $\begin{array}{l}\text { MAF Conv. } \\
(\%)^{b, c}\end{array}$ & $\begin{array}{l}\mathrm{DP}_{\mathrm{n}}^{b, d} \\
\left(\mathrm{DP}_{\mathrm{n}}^{b, e}\right)\end{array}$ & $\begin{array}{l}\text { OligoMAF } \\
\text { yield }(\%)^{f}\end{array}$ \\
\hline 1 & $\begin{array}{c}\text { No } \\
\text { additive }\end{array}$ & - & 11 & $2.3(2.2)$ & 15 \\
\hline 2 & $\begin{array}{l}\text { No } \\
\text { additive }\end{array}$ & $105^{\circ} \mathrm{C}, 63 \mathrm{~h}$ & 66 & 2.6 & - \\
\hline 3 & $\begin{array}{l}\text { No } \\
\text { additive }\end{array}$ & Toluene, $105^{\circ} \mathrm{C}, 63 \mathrm{~h}$ & 12 & 2.3 & - \\
\hline 4 & Radical & TBPPi (3.5 \%) & $15^{j}$ & $2.5(2.1)$ & - \\
\hline 5 & Base & KOH (5 \%) & 73 & $3.2(3.1)$ & - \\
\hline 6 & Base & $\begin{array}{c}2,2,6,6- \\
\text { Tetramethylpiperidine } \\
(5 \%)\end{array}$ & 71 & $3.0(2.6)$ & 57 \\
\hline 7 & Base & Piperidine (5 \%) & 76 & $3.5(3.0)$ & - \\
\hline 8 & Base & DBU (5 \%) & 76 & $3.1(3.0)$ & 49 \\
\hline 9 & Base & DIPEA (5 \%) & 78 & $3.1(3.4)$ & - \\
\hline 10 & Base & $\mathrm{P}\left({ }^{n} \mathrm{Bu}\right)_{3}(5 \%)$ & 66 & $3.2(2.9)$ & - \\
\hline 11 & Base & $\mathrm{P}\left(\mathrm{C}_{6} \mathrm{H}_{11}\right)_{3}(5 \%)$ & 73 & $2.9(3.2)$ & - \\
\hline 12 & Base & racemic BINAP (2.5 \%) & 76 & $2.7(3.1)$ & 32 \\
\hline 13 & Base & $\mathrm{PPh}_{3}(0.5 \%)$ & 83 & $3.5(3.3)$ & - \\
\hline 14 & Base & $\mathrm{PPh}_{3}(5 \%)$ & 71 & $3.3(3.0)$ & - \\
\hline $14 \mathrm{~A}$ & Base & $\begin{array}{c}\mathrm{PPh}_{3}(5 \%) \\
\mathrm{MgSO}_{4}(5 \%), 17 \mathrm{~h}\end{array}$ & 71 & $3.1(2.8)$ & - \\
\hline 14B & Base & $\begin{array}{c}\mathrm{PPh}_{3}(5 \%) \\
\mathrm{MgSO}_{4}(5 \%)\end{array}$ & 71 & $2.9(2.9)$ & - \\
\hline $14 \mathrm{C}$ & Base & $\begin{array}{c}\mathrm{PPh}_{3}(5 \%) \\
\mathrm{MgSO}_{4}(5 \%), 41 \mathrm{~h}\end{array}$ & 66 & $3.2(2.7)$ & - \\
\hline 15 & Base & $\mathrm{PPh}_{3}(5 \%), 60^{\circ} \mathrm{C}$ & 73 & $3.5(3.8)$ & - \\
\hline 16 & Base & $\mathrm{PPh}_{3}(5 \%), 80^{\circ} \mathrm{C}$ & 87 & 3.5 & - \\
\hline 17 & Base & $\mathrm{PPh}_{3}(5 \%), 120^{\circ} \mathrm{C}$ & $--^{g}$ & - & - \\
\hline 18 & Base & $\mathrm{PPh}_{3}(10 \%)$ & 79 & $2.8(2.6)$ & - \\
\hline 19 & Base & $\mathrm{PPh}_{3}(20 \%), 10 \mathrm{~min}$ & $-{ }^{g}$ & - & - \\
\hline 20 & Acid & $\mathrm{HCl}_{\mathrm{aq} 35 \%}(8 \%)$ & 26 & $2.9(2.1)$ & - \\
\hline 21 & Acid & $\mathrm{FeSO}_{4} .7 \mathrm{H}_{2} \mathrm{O}(5 \%)$ & 14 & $1.9(1.7)$ & - \\
\hline 22 & Acid & $\mathrm{B}\left(\mathrm{C}_{6} \mathrm{~F}_{5}\right)_{3}(5 \%)$ & 10 & $2.2(2.1)$ & - \\
\hline 23 & Acid & $\mathrm{AlCl}_{3}(5 \%)$ & 72 & $3.5(3.5)$ & - \\
\hline 24 & Acid & $\mathrm{MgSO}_{4}(5 \%)$ & 13 & $2.2(2.1)$ & - \\
\hline 25 & Acid & PTSA. $\mathrm{H}_{2} \mathrm{O}(5 \%)$ & 43 & $2.3(2.5)$ & - \\
\hline 26 & Acid & Triflic acid (5 \%) & 67 & $2.6(2.6)$ & - \\
\hline 27 & Acid/Base & $\mathrm{PPh}_{3}(5 \%)$ & 81 & 3.3 & - \\
\hline
\end{tabular}


$\mathrm{AlCl}_{3}(5 \%), 60^{\circ} \mathrm{C}$

28 Acid/Base $\mathrm{PPh}_{3}(5 \%), \mathrm{AlCl}_{3}(5 \%), \quad 69 \quad 3.1(3.2)$

Toluene, $60^{\circ} \mathrm{C}, 63 \mathrm{~h}$

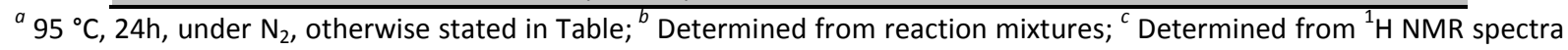
and equation (1) or $\left(1^{\prime}\right) ;{ }^{d}$ Determined from ${ }^{1} \mathrm{H}$ NMR spectra and equation (3) or $\left(3^{\prime}\right) ;{ }^{e}$ Determined from ${ }^{19} \mathrm{~F}$ NMR spectra and equation (4); ${ }^{f}$ Determined from ${ }^{1} \mathrm{H}$ NMR spectra of reaction mixtures after work-up (ammonium elimination and MAF sublimation); ${ }^{g}$ with other unidentified product(s).

TBPPi, DBU, DIPEA and PTSA stand for tert-butylperoxypivalate, 1,8-diazabicyclo[5.4.0]undec-7-ene, $N, N$ diisopropylethylamine and $p$-toluenesulfonic acid, respectively.

\section{Radical additives}

Though MAF is known not to homopolymerise under radical initiation, ${ }^{19,20}$ Aglietto et al. ${ }^{24}$ reported that tert-butylcyclohexyl peroxydicarbonate led to low molar mass oligomers in poor yield. tertButylperoxypivalate (TBPPi) (3.5 mol\%) was attempted as initiator for a radical trial, but did not lead to any remarkable change of MAF conversion (Entry 4 - Table 1).

\section{Basic additives}

Inorganic base as $\mathrm{KOH}$ led to high MAF conversion (76\%) and a $\mathrm{DP}_{\mathrm{n}}$ of 3.2 (Entry 5 - Table 1). Hindered secondary and tertiary amines such as piperidine, 2,2,6,6-tetramethylpiperidine, $N, N$ diisopropylethylamine (DIPEA) and 1,8-diazabicyclo[5.4.0]undec-7-ene (DBU) afforded the oligomers with almost the same results (MAF conversion of 71-78 \% and $\left.D P_{n}=3.1-3.7\right)($ Entries 6-9 - Table 1).

Different aliphatic and aromatic phosphines such as $\mathrm{P}\left({ }^{n} \mathrm{Bu}\right)_{3}, \mathrm{P}\left(\mathrm{C}_{6} \mathrm{H}_{11}\right)_{3}, \mathrm{PPh}_{3}(5$ mol\%) and racemic (2,2'-bis(diphenylphosphino)-1,1'-binaphthyl), BINAP, (2.5 mol\%), led to almost good MAF conversions (66-76 \%) and $\mathrm{DP}_{\mathrm{n}}$ (2.7-3.3) (Entries 10 - 12, 14 - Table 1). Highest $\mathrm{DP}_{\mathrm{n}}$ value was obtained when the reaction was catalyzed by $\mathrm{PPh}_{3}$, the loading of which was then considered.

Lower $\mathrm{PPh}_{3}$ loading $\left(0.5\right.$ mol\%) or temperatures $\left(60\right.$ and $80^{\circ} \mathrm{C}$ ) (Entries 13, 15, 16 - Table 1 ) led to same $\mathrm{DP}_{\mathrm{n}}$ (3.5) and higher MAF conversions (73-87 \%). But higher $\mathrm{PPh}_{3}$ loading (10 and $20 \mathrm{~mol} \%$ ) or temperature $\left(120^{\circ} \mathrm{C}\right)$ (Entries $17-19$, Table 1 ) gave lower $\mathrm{DP}_{\mathrm{n}}(2.8)$ or undesired side-products which were not identified.

\section{$\underline{\text { Acidic additives }}$}

$\mathrm{HCl}$ simultaneously led to oligoMAF and unexpected $\mathrm{ClCH}_{2}-\mathrm{CH}\left(\mathrm{CF}_{3}\right) \mathrm{COOH}$ (MAF-Cl), resulted from electrophilic addition of $\mathrm{HCl}$ onto $\mathrm{C}=\mathrm{C}$ bond of MAF (Entry 20 - Table 1). MAF-Cl was intentionnally formed by adding $\mathrm{HCl}_{\mathrm{aq}} 35 \%$ to MAF (Scheme S3, Figures S27-S28), including NMR evidence. Lewis acids such as $\mathrm{FeSO}_{4} .7 \mathrm{H}_{2} \mathrm{O}, \mathrm{B}\left(\mathrm{C}_{6} \mathrm{~F}_{5}\right)_{3}$ almost did not improve the reaction (Entries 21, 22 - Table 1). $\mathrm{AlCl}_{3}$ 
yielded satisfactory MAF conversion into oligomers with $\mathrm{DP}_{4.5}$ but also to $\mathrm{ClCH}_{2}-\mathrm{CH}\left(\mathrm{CF}_{3}\right) \mathrm{COOH}(13 \%)$ (Entry 23 - Table 1, Figure S19). It is worth to note that $\mathrm{AlCl}_{3}$ is known as a Lewis-acid catalyst for electrophilic chlorination of aromatic rings or of alcohols. ${ }^{42}$ Indeed, vinylic chlorination with $\mathrm{AlCl}_{3}$ requires benzeneseleninyl chloride. ${ }^{43}$ In addition, chlorination of fluorinated telomers was also succesfully achevied in presence of $\mathrm{AlCl}_{3}{ }^{44}$ To the best of our knowledge, the use of $\mathrm{AlCl}_{3}$ as a chlorine source for chlorination of fluorinated olefin has not been reported so far.

Organic Brønsted acid such as $p$-toluenesulfonic acid monohydrate (PTSA. $\mathrm{H}_{2} \mathrm{O}$ ) and triflic acid increased the MAF conversion to 43 and $67 \%$, respectively, but with low $\mathrm{DP}_{\mathrm{n}}$ were produced $(2.3$ and 2.6) (Entries 25-26 - Table 1).

\section{Other parameters}

Low MAF conversion might be due to the presence of water molecules, as in cases of PTSA. $\mathrm{H}_{2} \mathrm{O}$ and $\mathrm{FeSO}_{4} .7 \mathrm{H}_{2} \mathrm{O}$ (Entries 21 and 25 - Table 1). To verify it, $\mathrm{MgSO}_{4}$ that traps water was used and slightly increased the MAF conversion (Entry 24 - Table 1) but did not lead to any significative change in the presence of $\mathrm{PPh}_{3}$ (Entry 14B - Table 1).

From different reaction times $\left(17,24\right.$ and 41 h), slight differences of $\mathrm{DP}_{\mathrm{n}}$ (2.9-3.2) and MAF conversions (66-71 \%) were observed (Entries 14A - 14C - Table 1).

\section{Screening of additive combinations}

As using $\mathrm{PPh}_{3}$ and $\mathrm{AlCl}_{3}$ separately led to good results, our next interest was exploiting the reactivity of their combination, as a Lewis acid base couple. It was barely possible to perform the reaction catalysed by both of $\mathrm{AlCl}_{3}$ and $\mathrm{PPh}_{3}$ at $95{ }^{\circ} \mathrm{C}$ because the additives mixture turned to red then to black in a few seconds, indicating its burning before MAF melting $\left(60^{\circ} \mathrm{C}\right)$. In other cases, MAF played the role of solvent. Lower temperature $\left(60^{\circ} \mathrm{C}\right)$ (Entry $27-$ Table 1 ) was then attempted and the same $\mathrm{DP}_{\mathrm{n}}$ (3.3) was observed with $81 \%$ MAF conversion, which is slightly better than the result obtained with only $\mathrm{PPh}_{3}$ at $95^{\circ} \mathrm{C}$ (Entry $14-$ Table 1 ). Toluene was also used as the solvent to " homogenise » the mixture. Similar to the no-additive procedure mentionned above (Entries 2-3 - Table 1), the presence of toluene led to lower MAF conversion (69\%) and $\mathrm{DP}_{\mathrm{n}}$ (3.1) (Entry 28 - Table 1). In these two attempts, $\mathrm{ClCH}_{2}-\mathrm{CH}\left(\mathrm{CF}_{3}\right) \mathrm{COOH}$ was also obtained in low yields (13\%).

Finally, the best conditions for high MAF conversion (83-87 \%) were achieved in presence of $\mathrm{PPh}_{3}(0.5$ $\%$ at $95{ }^{\circ} \mathrm{C}$ or $5 \%$ at $80{ }^{\circ} \mathrm{C}$ ) for $\mathrm{DP}_{\mathrm{n}}$ of 3.5. As a matter of fact, a slight difference of $\mathrm{DP}_{\mathrm{n}}$ values was observed according to the analysis but the results are still consistent when supplied from the same method. OligoMAF obtained without additive (Entry 2 - Table 1) had $\mathrm{DP}_{2.6}$ from ${ }^{1} \mathrm{H} N \mathrm{NMR}$ and $\mathrm{DP}_{5}$ from MALDI-TOF, while the one obtained with DIPEA (Entry 9 - Table 1) had DP ${ }_{3.1}$ from ${ }^{1} \mathrm{H}$ NMR and 
$\mathrm{DP}_{6}$ from MALDI-TOF). MAF removal was applied on some of reactions and showed relative coherence with calculated MAF conversions. However, retro oxa-Michael was observed during the sublimation of oligoMAF phosphonium (Scheme S2).

\subsection{Mechanisms of the dimerisation of MAF by oxa-Michael addition}

In order to explain these obtained results, the oligomerisation mechanisms, classified by additive types, were considered. To simplify the discussion, only dimerisation mechanisms are supplied.

\section{Without additive}

Without any additive, two molecules of MAF could undergo an intermolecular oxa-Michael addition, affording diMAF via a typical six-membered transition state ${ }^{45}$ Int1, eventually disfavored by the poor electron $\mathrm{C}=\mathrm{C}$ bond (Scheme $4-$ first mechanism).<smiles>C=C(C(=C)C(F)(F)F)C(=O)O[Hg]O[CH]OC(=C)C(F)(F)F</smiles>

Figure 10 : Possible rearrangment by intermolecular hydrogen bond of MAF

Furthermore, the rearrangment by intermolecular hydrogen bond of MAF Int1' (Figure 10), corresponding to a eight membered transition state that dominates the desired reaction and led to low MAF conversion. MAF can also be considered as a Brønsted acid that catalyses the reaction, the mechanism of which is described below (Scheme $4-$ fourth mechanism). 
Without additive

$[\prod_{\text {Int1 }}^{O H} \rightarrow \underbrace{C}_{\mathrm{CO}_{2} \mathrm{H}}$

$$
\text { Brønsted base (B) }
$$

Lewis base (LB)

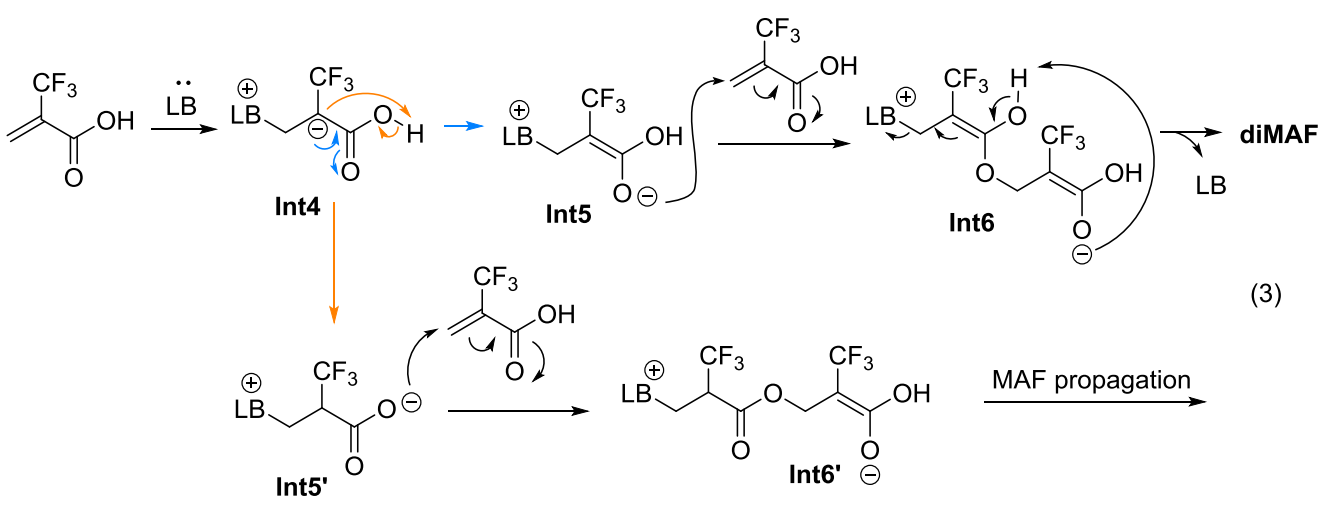

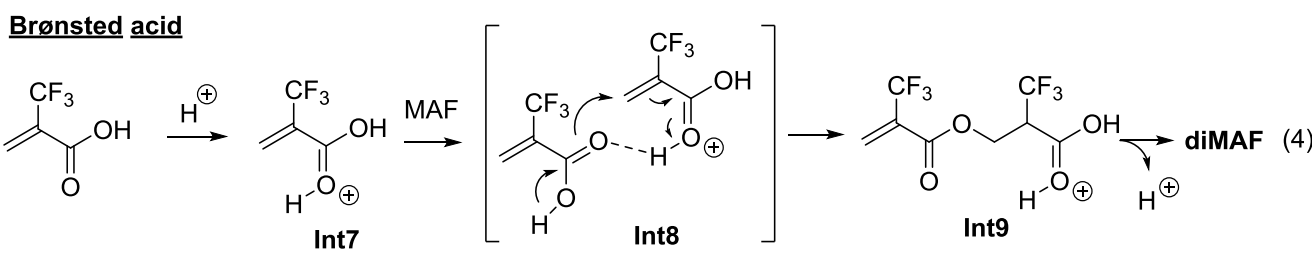

Scheme 4 : Mechanisms of dimerisation of MAF by oxa-Michael addition under different acidic and basic conditions

\section{$\underline{\text { Basic additives }}$}

In the presence of a Brønsted base (such as $\mathrm{KOH}$ or secondary and tertiary amines), MAF would be deprotonated to generate carboxylate Int2 that attacks, as a nucleophile, an second MAF molecule. The resulting carboxylate Int3 is then protonated to afford diMAF (Scheme 4 - second mechanism). ${ }^{46}$ By using Lewis base (such as tertiary phosphines $\mathrm{PR}_{3}$ ), the nucleophilic conjugate addition of the Lewis base on the vinyl group of MAF takes place to form the zwitterion Int4, known as the activated specy of Morita-Baylis-Hilman or Rauhut-Currier reactions. ${ }^{47,48}$ Int4 can undergo a rearrangment to yield Int5, that propagates to form Int6. Int4 might also undergo a proton migration to give carboxylate Int5' that is then added onto the vinyl group of a second MAF molecule to yield 
intermediate Int6'. According to the ${ }^{31} \mathrm{P}$ NMR spectrum (Figure S26), the Lewis base was not eliminated at the end of the reactions. The desired diMAF was then obtained with its phosphinated derivates (Scheme 4 - third mechanism). ${ }^{46}$

Tertiary amines act mostly like a Brønsted base in this reaction because of the domination of acidbase reaction vis-a-vis the conjugated addition. This was proved by the formation of the organic ammonium salt, $(\mathrm{RCOO})^{-}\left(\mathrm{R}_{2}^{\prime} \mathrm{NH}_{2}\right)^{+}$, when mixing equimolar 2,2,6,6-tetramethylpiperidine and MAF (Scheme 5). The vanishing of $\mathrm{COOH}$ signal was observed in ${ }^{1} \mathrm{H}$ NMR spectrum (Figure S25). The electrophilic addition adduct, of amine onto MAF $\mathrm{C}=\mathrm{C}$ bond, was not observed. ${ }^{16}$ With the steric hindrance, the ammonium cation should prevent from the propagation of the attached carboxylates.

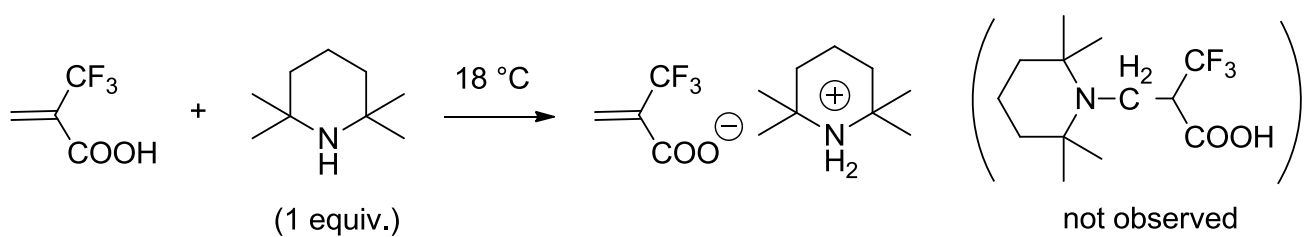

Scheme 5: Formation of the organic ammonium salt from MAF and 2,2,6,6-tetramethylpiperidine

$\mathrm{PR}_{3}$ phosphines are less basic but more nucleophilic than similarly substituted amines $\mathrm{NR}_{3}$ and led clearly to third mechanism. ${ }^{49,50}$ Additionnally, trialkylated phosphines are more nucleophilic than $\mathrm{PPh}_{3}$, ${ }^{49,50}$ and therefore generate more Int6' species than $\mathrm{PPh}_{3}$ does, affording shorter oligomer chains. The availability of carboxylate group of phosphonium should promote the propagation and explain higher $\mathrm{DP}_{\mathrm{n}}$ of oligoMAF.

\section{Acidic additives}

The Brønsted acid (such as PTSA. $\mathrm{H}_{2} \mathrm{O}$ and triflic acid) activates the carboxylic acid function of MAF, triggering the conjugate addition in a six-membered transition state, affording Int9. A subsequent hydrogen shift gives diMAF (Scheme 4 - fourth mechanism). ${ }^{9,13}$

The Lewis acid (such as $\mathrm{FeSO}_{4} \cdot 7 \mathrm{H}_{2} \mathrm{O}$ and $\mathrm{B}\left(\mathrm{C}_{6} \mathrm{~F}_{5}\right)_{3}$ ) did not promote the oligomerisation, giving low $\mathrm{MAF}$ conversions and $\mathrm{DP}_{\mathrm{n}}$. It is worth to know that heating the equimolar MAF and MAF-Cl mixture at $95{ }^{\circ} \mathrm{C}$ for 1 day did not lead to any conversion (Scheme S4). No reasonnable explanation of high $\mathrm{DP}_{\mathrm{n}}$ when using $\mathrm{AlCl}_{3}$ can be given.

No matter the pathway, the key Int3, Int6, Int6'and Int9 intermediates are able to undergo further Michael addition to propagate the oligomer chains. 


\section{MAF polymerisation pathways}

MAF can undergo homopolymerisation with two different monomer units: - $\left[\mathrm{CH}_{2}-\mathrm{C}\left(\mathrm{CF}_{3}\right)(\mathrm{COOH})\right]-$ unit formed via $\mathrm{C}=\mathrm{C} \pi$ bond cleavage, under basic conditions ${ }^{21-23}$ and $-\left[\mathrm{CH}_{2}-\mathrm{CH}\left(\mathrm{CF}_{3}\right)-\mathrm{COO}\right]-$ unit formed from the oxa-Michael addition (Scheme 6). The latter reaction was underdevelopped in the literature ${ }^{29,30}$ and therefore can be highlighted in this present study. The $-\left[\mathrm{C}\left(\mathrm{CF}_{3}\right)(\mathrm{COOH})-\mathrm{CH}_{2}\right]-$ unit is simplified to $\left(-\mathrm{C}^{\cap} \mathrm{C}-\right)$, as the fragment starts and ends by $\mathrm{C}$ atoms. The $-\left[\mathrm{CH}_{2}-\mathrm{CH}\left(\mathrm{CF}_{3}\right)-\mathrm{COO}\right]-$ unit is symbolised by (- $\left.\mathrm{C}^{\cap} \mathrm{O}-\right)$, as the fragment starts from a $\mathrm{C}$ atom and ends with an $\mathrm{O}$ atom.

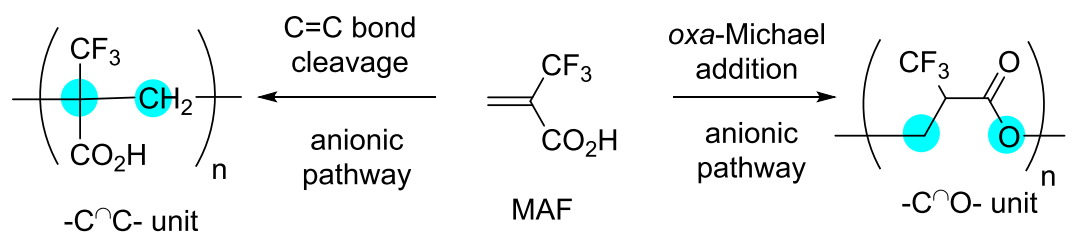

Scheme 6: $-\left[\mathrm{C}\left(\mathrm{CF}_{3}\right)(\mathrm{COOH})-\mathrm{CH}_{2}\right]-\left(-\mathrm{C}^{\cap} \mathrm{C}-\right)$ unit formed via $\mathrm{C}=\mathrm{C}$ bond cleavage of $\mathrm{MAF}$ and $-\left[\mathrm{CH}_{2}-\mathrm{CH}\left(\mathrm{CF}_{3}\right)-\mathrm{COO}_{-}-\left(-\mathrm{C}^{\cap} \mathrm{O}-\right)\right.$ monomer unit generated via oxa-Michael addition.

The $\left(-C^{n} C_{-}\right)$and (- $\left.C^{n} \mathrm{O}-\right)$ units of polyMAF can be also differenciated by ${ }^{13} \mathrm{C}$ NMR spectroscopy. Concerning ( $\left.-\mathrm{C}^{n} \mathrm{C}-\right)$ unit, a previous article ${ }^{51}$ reports the alternating copolymerisation of vinyl acetate (VAc) with tert-butyl-2-trifluoromethacrylate (MAFTBE). The resulting poly(VAc-alt-MAFTBE) copolymers were hydrolyzed into $\mathrm{NC}-\mathrm{CH}_{2}-\left[\mathrm{CH}_{2}-\mathrm{CH}(\mathrm{OH})-\mathrm{CH}_{2}-\mathrm{C}\left(\mathrm{CF}_{3}\right)(\mathrm{COOH})\right]_{n}-\mathrm{SH}$. As a comparison, the ${ }^{13} \mathrm{C}$ NMR spectrum (Figure $11 \mathrm{C}$ ) displays an expected quartet $\left({ }^{1} J_{\mathrm{CF}}=280 \mathrm{~Hz}\right)$ centered at $127 \mathrm{ppm}$ assigned to $\mathrm{CF}_{3} \boldsymbol{a}^{3}$, slightly low shield shifted compared to $\boldsymbol{a}, \boldsymbol{a}^{1}$ and $\boldsymbol{a}^{2}$. The quartet at $54.74 \mathrm{ppm}\left({ }^{2} J_{\mathrm{CF}}\right.$ $=30 \mathrm{~Hz}$ ) is attributed to the quaternary carbon atom $\boldsymbol{b}^{3}$ while $\mathrm{COO} c^{3}$ is represented by a signal at $176.16 \mathrm{ppm}$. The broad signal centered in the 35.8-45.4 ppm range is assigned to $-\mathrm{CH}_{2}-\boldsymbol{d}^{3}$ and $\mathrm{CH}_{2}$ in vinyl alcohol unit. 


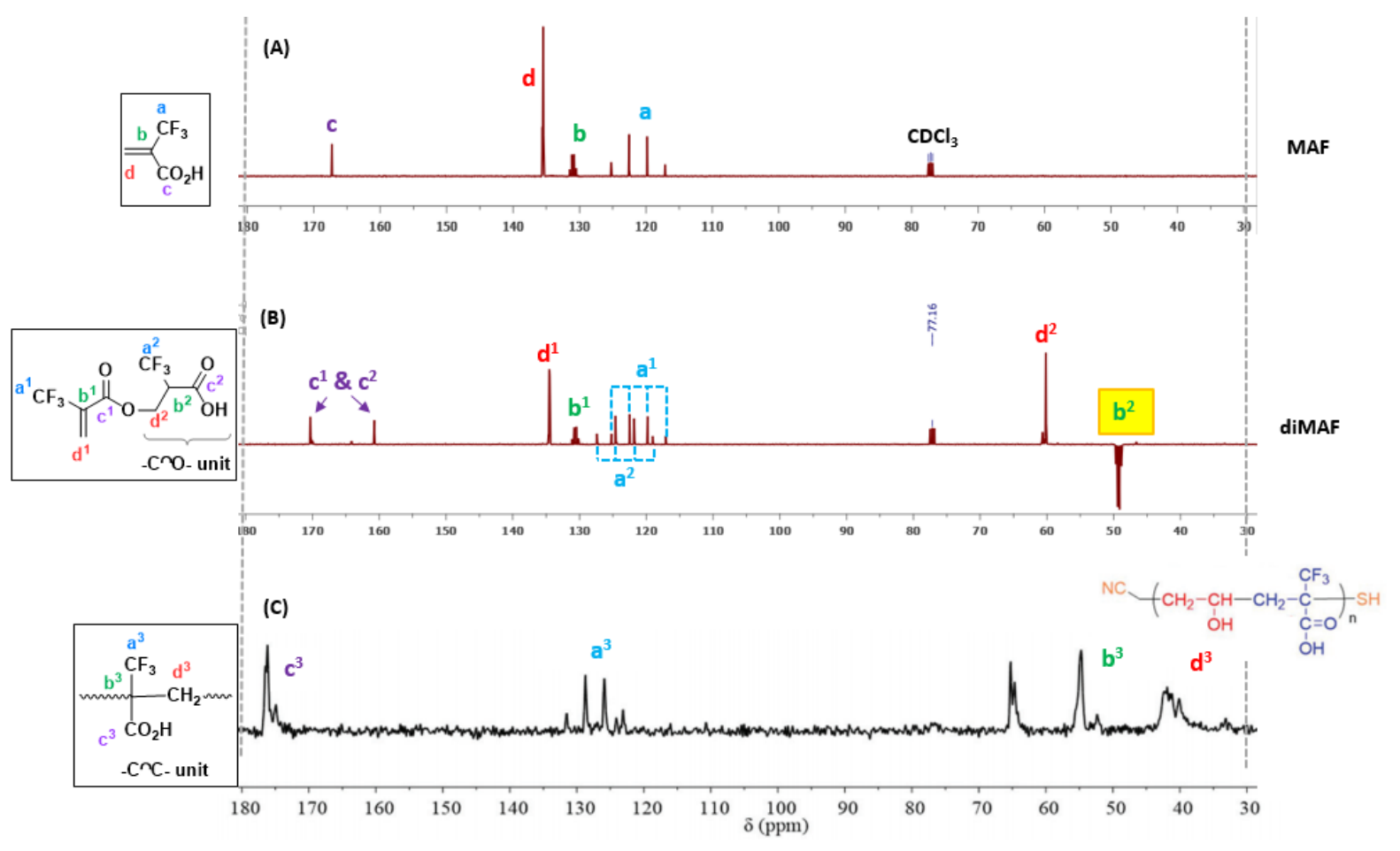

Figure $11:{ }^{13} \mathrm{CNMR}$ spectra of MAF (top-recorded in $\mathrm{CDCl}_{3}$ ); of diMAF (APT spectrum- middle-recorded in $\mathrm{CDCl}_{3}$ ) and $\mathrm{NC}$ $\mathrm{CH}_{2}-\left[\mathrm{CH}_{2}-\mathrm{CH}(\mathrm{OH})-\mathrm{CH}_{2}-\mathrm{C}\left(\mathrm{CF}_{3}\right)(\mathrm{COOH})\right]_{n}-\mathrm{SH}$ copolymer (bottom-recorded in $\mathrm{D}_{2} \mathrm{O}$, extracted from Polym. Chem. 2021, 12, 277).

The most important clue of the (- $\left.\mathrm{C}^{\cap} \mathrm{O}-\right)$ unit is the tertiary carbon $-\mathrm{CH}-\boldsymbol{b}^{2}$ at $49.35 \mathrm{ppm}$ which is neither present in MAF nor in (- $\left.\mathrm{C}^{n} \mathrm{C}-\right)$ unit structures. The APT mode of ${ }^{13} \mathrm{C}$ NMR spectrum allows to evidence $-\mathrm{CH}$ - signal, found in the opposite side of secondary and quaternary carbons signals. Additionnally, directly attached to a $\mathrm{CF}_{3}$ group, it displays a quartet with ${ }^{2} J_{\mathrm{CF}} \approx 30 \mathrm{~Hz}$ (Figure $11 \mathrm{~B}$ ). Indeed, the absence of signal at $55 \mathrm{ppm}$ attributed to $-\mathrm{CH}_{2}-\mathrm{C}\left(\mathrm{CF}_{3}\right)(\mathrm{COOH})-\mathrm{CH}_{2}$ - of the copolymer evidences the absence of radical homopolymerisation (Figure 11C).

\section{Conclusion}

This study reports the oxa-Michael oligomerisation of MAF in various conditions : in the absence of catalyst, in the presence of Brønsted acids, Brønsted and Lewis bases. The additives screening showed that the oligomerisation of MAF was not promoted in the radical way and confirms previous studies. ${ }^{19,20}$ Brønsted acids and bases led to oligomers with good MAF conversions but in low DP . $\mathrm{Et}_{3} \mathrm{~N}$, in the Japanese patent, ${ }^{29}$ does not seem to be the optimal reactant to get high $\mathrm{DP}_{\mathrm{n}}$. The reaction can be also assisted by triflic acid as Brønsted acid, which gives good MAF conversion (67\%) and average $\mathrm{DP}_{\mathrm{n}}$ (2.6). Mostly, Lewis acids do not favor the desired reaction. Particularly, the use of $\mathrm{AlCl}_{3}$ allowed to reach a $\mathrm{DP}_{\mathrm{n}}$ of 4.1 but simultaneously gave $\mathrm{ClCH}_{2}-\mathrm{CH}\left(\mathrm{CF}_{3}\right) \mathrm{COOH}$ as a by-product. Brønsted bases such as hindered tertiary amines and phosphines led to good MAF conversions. The best results of this screening were obtained with $\mathrm{PPh}_{3}$ and piperidine, similarly to the oxa-Michael 
addition polymerisation of acrylic acid. The use of $\mathrm{PPh}_{3}\left(\left(0.5 \%\right.\right.$ at $95{ }^{\circ} \mathrm{C}$ or $5 \%$ at $\left.80{ }^{\circ} \mathrm{C}\right)$ yielded good MAF conversions (83-87 \%) and $\mathrm{DP}_{\mathrm{n}}(3.5)$ but the purification of phosphoniums is delicate because MAF removal process favors led to retro oxa-Michael reaction. The piperidine lead also to correct MAF conversion (76\%) and $\mathrm{DP}_{\mathrm{n}}$ (3.5). This study might be developped in copolymerisation processes with diols, vinylsulfones or sulfonate derivatives. ${ }^{9,52,53}$

\section{Acknowledgements}

The authors thank the Tosoh Fine Chemical Company for supplying free sample of MAF and Prof. David Virieux for advice and discussion.

\section{Conflict of Interets}

The authors declare there is no conflict of interest.

\section{$\underline{\text { References }}$}

(1) Williams, C. K. Synthesis of Functionalized Biodegradable Polyesters. Chem. Soc. Rev. 2007, 36 (10), 1573.

(2) Satti, S. M.; Shah, A. A. Polyester-Based Biodegradable Plastics: An Approach towards Sustainable Development. Lett. Appl. Microbiol. 2020, 70 (6), 413-430.

(3) Panchal, S. S.; Vasava, D. V. Biodegradable Polymeric Materials: Synthetic Approach. ACS Omega 2020, 5 (9), 4370-4379.

(4) Feghali, E.; Tauk, L.; Ortiz, P.; Vanbroekhoven, K.; Eevers, W. Catalytic Chemical Recycling of Biodegradable Polyesters. Polym. Degrad. Stab. 2020, 179, 109241.

(5) Knochel, P. Comprehensive Organic Synthesis, 2nd ed.; Elsevier, 2014.

(6) Jha, A.; Inani, H.; Easwar, S. A Nucleophilic Activation of Carboxylic Acids by Proline: OxaMichael Addition to Methyl Vinyl Ketone under Solvent-Free Conditions. Synlett 2017, 28 (12), 1473-1477.

(7) Wang, X.; Zhu, X.; Jiang, W.; Gao, Y. Synthesis of Esters via Sodium Carbonate Promoted OxaMichael Addition of Acids to $\alpha, \beta$-Unsaturated Ketones. Chinese J. Org. Chem. 2019, 39 (5), 1383.

(8) Peterson, C. J.; Bowden, E.; Chapman, J. T.; Mueller, S. Processes for Separating Crude Acrylic Acids and Acrylates Comprising A Michael Addition Product. US2014378702A1, 2014.

(9) Murase, T.; Matsuoka, S.; Suzuki, M. Hydrogen-Transfer and Condensation-Addition Polymerizations of Acrylic Acid. Polym. Chem. 2018, 9 (21), 2984-2990.

(10) Zhang, C.; Chen, M. Method for Preparing Acrylic Acid Addition Polymer Using Acidic Catalyst. CN109879751A, 2019.

(11) Zhang, C.; Chen, M. Method for Preparing Acryloyloxy Propionate Compound. CN109776312A, 2019.

(12) Fujita, M.; lizuka, Y.; Miyake, A. Thermal and Kinetic Analyses on Michael Addition Reaction of Acrylic Acid. J. Therm. Anal. Calorim. 2017, 128 (2), 1227-1233. 
(13) Pfeifer, C. A.; Scholz, C.; Vogel, K.; Drochner, A.; Vogel, H. Formation of By-Products in Pure and Aqueous Acrylic Acid - Kinetic Measurements and Formation Mechanisms. Chem. Eng. Technol. 2017, 40 (4), 755-759.

(14) Wampler, F. M. Formation of Diacrylic Acid during Acrylic Acid Storage. Plant/Operations Prog. 1988, 7 (3), 183-189.

(15) Matsuoka, S.; Namera, S.; Suzuki, M. Oxa-Michael Addition Polymerization of Acrylates Catalyzed by N-Heterocyclic Carbenes. Polym. Chem. 2015, 6 (2), 294-301.

(16) Fuchikami, T.; Yamanouchi, A.; Ojima, I. An Effective and Convenient Route to 5Trifluoromethyl-5,6-Dihydrouracils and Their Thio Derivatives. Synthesis (Stuttg). 1984, 1984 (09), 766-768.

(17) Patil, Y.; Ameduri, B. Advances in the (Co)Polymerization of Alkyl 2-Trifluoromethacrylates and 2-(Trifluoromethyl)Acrylic Acid. Prog. Polym. Sci. 2013, 38 (5), 703-739.

(18) Banerjee, S.; Ameduri, B. Emerging Opportunities in (Co)Polymerization of Alkyl 2(Trifluoromethyl)Acrylates and 2-(Trifluoromethyl)Acrylic Acid and Their Applications. In Frontiers of Organofluorine Chemistry; Ojima, I., Ed.; World Scientific (Europe), 2020, Chapter 17; pp 735-779.

(19) Ito, H.; Giese, B.; Engelbrecht, R. Radical Reactivity and Q-e Values of Methyl $\alpha$ (Trifluoromethyl)Acrylate. Macromolecules 1984, 17 (10), 2204-2205.

(20) McElroy, K. T.; Purrington, S. T.; Bumgardner, C. L.; Burgess, J. P. Lack of Polymerization of Fluorinated Acrylates. J. Fluor. Chem. 1999, 95 (1-2), 117-120.

(21) Narita, T.; Hagiwara, T.; Hamana, H.; Nara, T. Anionic Polymerization of Ethyl 2Trifluoromethylacrylate. Die Makromol. Chemie, Rapid Commun. 1985, 6, 301.

(22) Narita, T.; Hagiwara, T.; Hamana, H.; Maesaka, S. Anionic Polymerization of Fluoroalkyl 2Trifluoromethylacrylate. Polym. J. 1988, 20 (6), 519.

(23) Narita, T. Anionic Polymerization of Fluorinated Vinyl Monomers. Prog. Polym. Sci. 1999, 24, 1095.

(24) Aglietto, M.; Passaglia, E.; di Mirabello, L. M.; Botteghi, C.; Paganelli, S.; Matteoli, U.; Menchi, G. Synthesis of New Polymers Containing $\alpha$-(Trifluoromethyl)-Acrylate Units. Macromol. Chem. Phys. 1995, 196 (9), 2843-2853.

(25) Ito, H.; Miller, D. C. Radical Copolymerization of 2-Trifluoromethylacrylic Monomers. I. Kinetics of Their Copolymerization with Norbornenes and Vinyl Ethers as Studied by in Situ $1 \mathrm{H}$ NMR Analysis. J. Polym. Sci. Part A Polym. Chem. 2004, 42 (6), 1468-1477.

(26) Ito, H.; Okazaki, M.; Miller, D. C. Radical Copolymerization of 2-Trifluoromethylacrylic Monomers. II. Kinetics, Monomer Reactivities, and Penultimate Effect in Their Copolymerization with Norbornenes and Vinyl Ethers. J. Polym. Sci. Part A Polym. Chem. 2004, $42(6), 1478-1505$.

(27) Cracowski, J.-M.; Montembault, V.; Odobel, F.; Améduri, B.; Fontaine, L. Synthesis and Characterization of Poly(Fluorinated Vinyl Ether- Alt-Tert -Butyl $\alpha$-Trifluoromethacrylate) Copolymers. J. Polym. Sci. Part A Polym. Chem. 2009, 47 (22), 6116-6123.

(28) Souzy, R.; Ameduri, B.; Boutevin, B. Radical Copolymerization of $\alpha$-Trifluoromethylacrylic Acid with Vinylidene Fluoride and Vinylidene Fluoride/Hexafluoropropene. Macromol. Chem. Phys. 2004, 205 (4), 476-485.

(29) Tokuhisa, K.; Mimura, H.; Kawada, K.; Arai, S. Perfluoroalkylacrylic Acid Polymers (Mixtures), Polymerization and Heat Decomposition Thereof, and Purification of Perfluoroalkylacrylic Acids Thereby. JP2003261512, 2003.

(30) Ansell, R. J.; Wang, D. Imprinted Polymers for Chiral Resolution of ( \pm )-Ephedrine. Part 3:NMR Predictions and HPLC Results with Alternative Functional Monomers. Analyst 2009, 134 (3), 564-576.

(31) Lai, E. P. C.; Feng, S. Y. Molecularly Imprinted Solid Phase Extraction for Rapid Screening of Metformin. Microchem. J. 2003, 75 (3), 159-168.

(32) Mao, Y.; Fung, B. M. A Study of the Adsorption of Acrylic Acid and Maleic Acid from Aqueous Solutions onto Alumina. J. Colloid Interface Sci. 1997, 191 (1), 216-221. 
(33) Kushida, K.; Wantanabe, A. Proton and Fluorine Nuclear Magnetic Resonance Spectral Data; Japan Halon Co., Ltd.: Tokyo, Japan, 1988.

(34) Li, X.; Baughman, J.; Gao, C.; Li, L.; Rinaldi, P. L.; Twum, E. B.; Mccord, E. F.; Wyzgoski, F. J. Multidimensional NMR of Fluoropolymers. In Handbook of Fluoropolymer Science and Technology; Jr., D. W. S., Iacono, S. T., Iyer, S. S., Eds.; John Wiley \& Sons, Inc.: Hoboken, NJ, USA, 2014; Chapter 24, pp 565-598.

(35) Roche, A. J.; Marchione, A. A. Investigation of the Correlations between $19 \mathrm{~F}$ and $1 \mathrm{H}$ NMR Signals for Various Mono- and Di-Substituted Octafluoro[2.2]Paracyclophanes. Magn. Reson. Chem. 2009, 47 (5), 428-436, and references within.

(36) Foris, A. 19F and 1H NMR Spectra of Halocarbons. Magn. Reson. Chem. 2004, 42 (6), 534-555.

(37) Zhang, Z.; Edkins, R. M.; Nitsch, J.; Fucke, K.; Steffen, A.; Longobardi, L. E.; Stephan, D. W.; Lambert, C.; Marder, T. B. Optical and Electronic Properties of Air-Stable Organoboron Compounds with Strongly Electron-Accepting Bis(Fluoromesityl)Boryl Groups. Chem. Sci. 2015, 6 (1), 308-321.

(38) Bartolomé, C.; Espinet, P.; Martín-Álvarez, J. M.; Villafañe, F. Bis(Fluoromesityl) Palladium Complexes, Archetypes of Steric Crowding and Axial Protection Byortho Effect- Evidence for Dissociative Substitution Processes-Observation of 19F-19F Through-Space Couplings. Eur. J. Inorg. Chem. 2004, 2004 (11), 2326-2337.

(39) Wang, S.; Yang, Q.; Chen, F.; Sun, J.; Luo, K.; Yao, F.; Wang, X.; Wang, D.; Li, X.; Zeng, G. Photocatalytic Degradation of Perfluorooctanoic Acid and Perfluorooctane Sulfonate in Water: A Critical Review. Chem. Eng. J. 2017, 328, 927-942.

(40) Boutevin, B.; Pietrasanta, Y. Les Acrylates et Polyacrylates Fluorés Dérivés et Applications; Erec: Paris, 1988.

(41) Koiry, B. P.; Klok, H.-A.; Singha, N. K. Copolymerization of 2,2,3,3,4,4,4-Heptafluorobutyl Acrylate with Butyl Acrylate via RAFT Polymerization. J. Fluor. Chem. 2014, 165, 109-115.

(42) Ma, H.; Bao, Z.; Bai, L.; Cao, W. A New Facile Route to Chlorination of Alcohols via Lewis Acid AlCl3. Int. J. Org. Chem. 2012, 02 (01), 21-25.

(43) Kamigata, N.; Satoh, T.; Yoshida, M. Reaction of Benzeneseleninyl Chloride with Olefins in the Presence of a Lewis Acid. A Novel One Step Vinylic Chlorination. Bull. Chem. Soc. Jpn. 1988, 61 (2), 449-454.

(44) Améduri, B.; Boutevin, B.; Lecrom, C.; Garnier, L. Synthesis of Halogenated Monodispersed Telechelic Oligomers. III. Bistelomerization of Allyl Acetate with Telogens Which Exhibit $\alpha, \omega-$ Di(Trichloromethyled) End Groups. J. Polym. Sci. Part A Polym. Chem. 1992, 30 (1), 49-62.

(45) Yang, J. Six-Membered Transition States in Organic Synthesis; John Wiley \& Sons, Inc.: Hoboken, NJ, USA, 2008.

(46) Nair, D. P.; Podgórski, M.; Chatani, S.; Gong, T.; Xi, W.; Fenoli, C. R.; Bowman, C. N. The ThiolMichael Addition Click Reaction: A Powerful and Widely Used Tool in Materials Chemistry. Chem. Mater. 2014, 26 (1), 724-744.

(47) Matsuoka, S. N-Heterocyclic Carbene-Catalyzed Dimerization, Cyclotetramerization and Polymerization of Michael Acceptors. Polym. J. 2015, 47 (11), 713-718.

(48) Matsuoka, S.; Hoshiyama, Y.; Tsuchimoto, K.; Suzuki, M. Oxa-Michael Addition Reaction and Polymerization of Morita-Baylis-Hillman Adducts and Derivatives. Chem. Lett. 2017, 46 (12), 1718-1720.

(49) Zhou, Z.; Wang, Y.; Tang, C. Nucleophilic Tertiary Phosphine Organocatalysts in Asymmetric Reactions. Curr. Org. Chem. 2011, 15 (24), 4083-4107.

(50) Sibbald, P. A. Nucleophilic Substitution Reactions Using Phosphine Nucleophiles: An Introduction to Phosphorus-31 NMR. J. Chem. Educ. 2015, 92 (3), 567-570.

(51) Falireas, P. G.; Ladmiral, V.; Ameduri, B. Synthesis, Aqueous Solution Behavior and SelfAssembly of a Dual PH/Thermo-Responsive Fluorinated Diblock Terpolymer. Polym. Chem. 2021, 12 (2), 277-290.

(52) Strasser, S.; Slugovc, C. Nucleophile-Mediated Oxa-Michael Addition Reactions of Divinyl Sulfone - a Thiol-Free Option for Step-Growth Polymerisations. Catal. Sci. Technol. 2015, 5 
(12), 5091-5094.

(53) Ziegenbalg, N.; Lohwasser, R.; D’Andola, G.; Adermann, T.; Brendel, J. C. Oxa-Michael Polyaddition of Vinylsulfonylethanol for Aliphatic Polyethersulfones. Polym. Chem. 2021, DOI: 10.1039/d1py00256b.

Table of Contents (TOC)

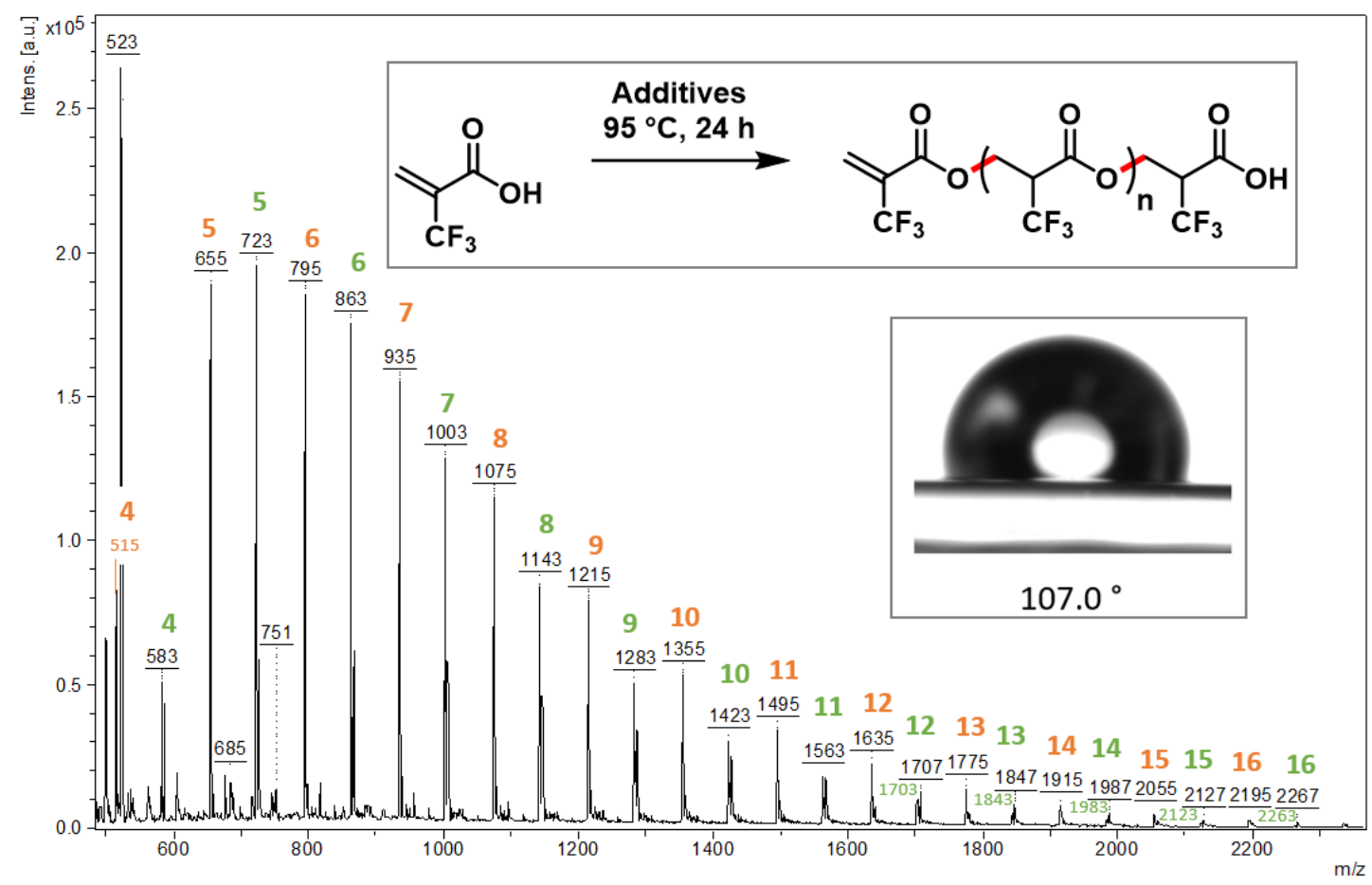

